\title{
An Overview of Authigenic Magnesian Clays
}

\author{
Manuel Pozo ${ }^{1, * \mathbb{D}}$ and José Pedro Calvo ${ }^{2}$ \\ 1 Department of Geology and Geochemistry, Faculty of Sciences, Universidad Autónoma de Madrid, \\ Campus de Cantoblanco, C/ Francisco Tomás y Valiente, 7, 28049 Madrid, Spain \\ 2 Department of Mineralogy and Petrology, Faculty of Geological Sciences, Universidad Complutense, \\ C/ José Antonio Novais, 12, 28040 Madrid, Spain; jpcalvo@ucm.es \\ * Correspondence: manuel.pozo@uam.es; Tel.: +34-91-497-4808
}

Received: 29 August 2018; Accepted: 7 November 2018; Published: 9 November 2018

\begin{abstract}
Clay authigenesis mostly concerns: (a) the formation of clays by direct precipitation from solution, called "neoformation" and (b) development of clays by transformation of precursor minerals. Precipitation from solution implies that a new mineral structure crystallizes, so that a prior mineral structure is not inherited. Transformation of precursor detrital minerals, a process also termed "neoformation by addition", can be conducted whether throughout precipitation on pre-existing natural surfaces or transformation and reaction on pre-existing surfaces. Both processes have been recognized as effective mechanisms in the formation of Mg-clays, which mostly include 2:1 clay minerals, such as talc-kerolite and Mg-smectites, as well as fibrous clays (sepiolite, palygorskite). Authigenic Mg-clay minerals occur in both modern and ancient marine and non-marine depositional environments, although formation of these clays in hydrothermal continental and seafloor settings must be also outlined. Most favourable conditions for the formation of Mg-clays on earth surface are found in evaporitic depositional environments, especially where parent rocks are enriched in ferromagnesian minerals. In these settings, $\mathrm{Mg}$-clays are important constituent of weathering profiles and soils and can form thick deposits of significant economic interest. Based on this review of authigenic clay deposits, we propose three geochemical pathways, mainly related to continental environments, for the origin of authigenic Mg-clays: formation of Al-bearing Mg-clays (pathway 1), formation of Al-free $\mathrm{Mg}$ clays (pathway 2) and formation of sepiolite from other Mg-clay minerals (pathway 3).
\end{abstract}

Keywords: sepiolite; palygorskite; magnesian smectites; talc-kerolite; lake deposits; peri-marine deposits; geochemical pathways

\section{Introduction}

This overview of Mg-rich clays is addressed to a broad geological audience who can be concerned with the environmental and/or paleoenvironmental information provided by the occurrence of Mg-clays in the earth surface. Content of the paper is mainly based on previous work by the authors and relevant recent contributions on the topic. These contributions can be analysed in more detail by inspecting the profuse list of references.

\subsection{The "Authigenesis" Concept}

Authigenic geologic materials are those "formed or generated in place", including rock constituents and minerals that have not been transported or that crystallized locally at the spot where they are now found and of minerals that came into existence at the same time as, or subsequent to, the formation of the rock in which they constitute a part [1]. According to this definition, authigenesis, first used by Kalkowsky [2], is a very open term describing a large number of diagenetic processes 
and stages. As a matter of fact, definitions of "authigenic" or "authigenesis" in digital platforms and/or dictionaries, for instance Wikipedia, are almost coincident with "sedimentation of chemical deposits and processes leading to lithification of sediments into rocks." Many years after the pioneering paper by Kalkowsy [3] and then Fairbridge [4] also used the term "authigenic" to define and describe the origin of any newly formed or secondary mineral, so that the broad sense of the concept was maintained through time.

\subsection{Overview of Authigenic Clay Minerals}

Focusing on clays, a distinction between "authigenic" and "diagenetic" has been made [5], underlining that the latter term describes clay minerals formed significantly after deposition. An outstanding point in the distinction is that diagenetic minerals do not reflect how the chemistry of the waters is in the depositional basin but rather what the chemistry of water is within the sediment pores after deposition.

Clay authigenesis mostly concerns two main processes [6-9]: (a) formation of clays by direct precipitation from solution, called "neoformation" and (b) development of clays by transformation of precursor, for example, pyroclastics and detrital clays, minerals (Figure 1). Regarding the former process, direct precipitation from solution containing either simple or complex ions implies that a new mineral structure crystallizes, so that a pre-existing mineral structure is not inherited.

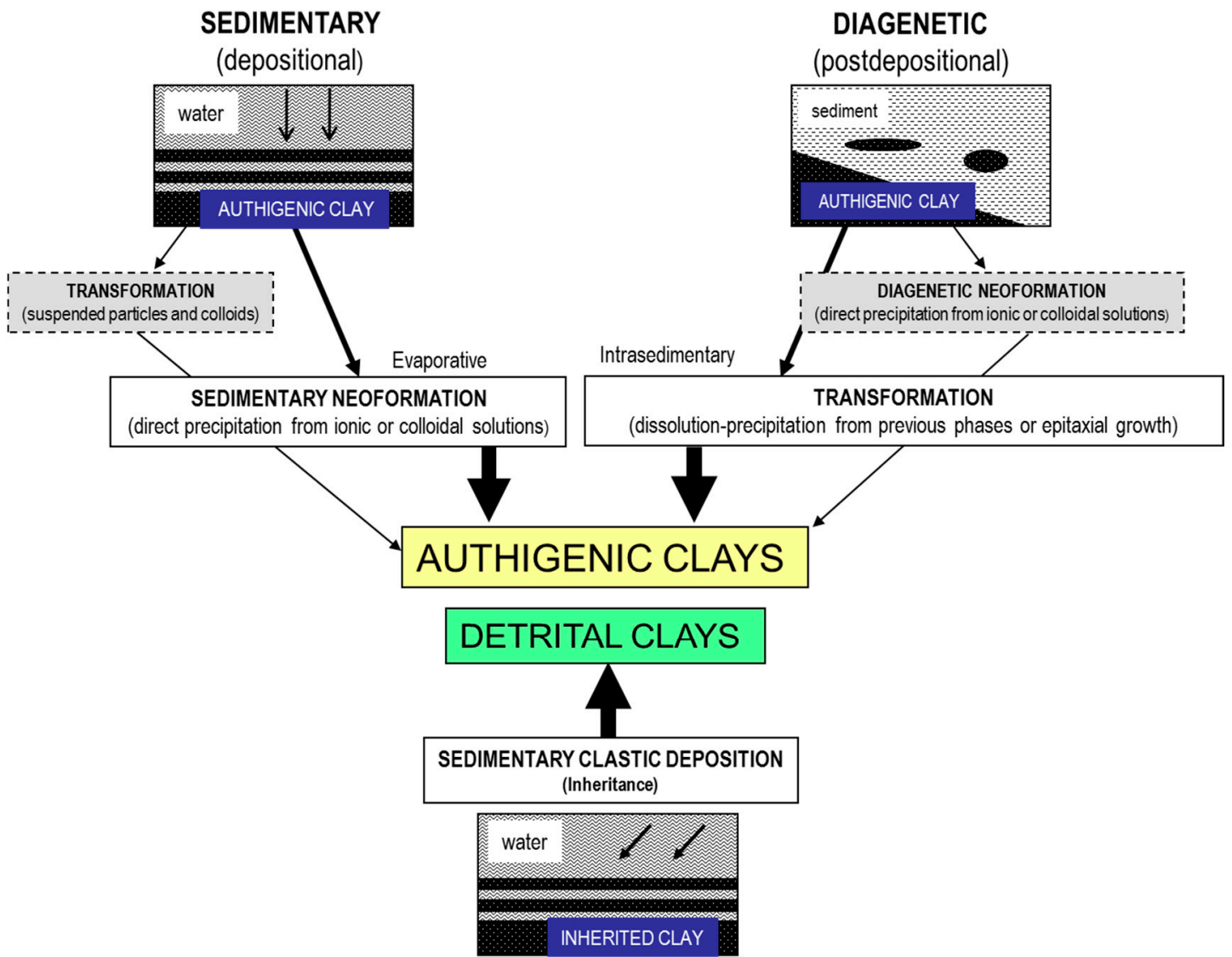

Figure 1. Diagrammatic sketch showing the relationships between detrital and authigenic clays with emphasis in their models of formation.

Formation of minerals from solution is mainly controlled by kinetics. The model for mineral nucleation and growth kinetics has been soundly established $[10,11]$. Two processes account for the precipitation of a mineral from water: nucleation, followed by crystal growth. Nucleation, involving the interaction between ions or molecules to form nuclei [12], is properly achieved when a solution is 
supersaturated with respect to a given solid phase or mineral. This way of nucleation from an aqueous solution is called homogeneous, in contrast to that occurring on the surface of a pre-existing solid (heterogeneous nucleation; see further comments).

Once nucleation has taken place, crystal growth can be accomplished either by addition of ions and/or molecules to the surface of crystal nuclei ("classical" crystal growth) [11]; or via the aggregation and subsequent attachment of crystal nuclei together ("nanoparticle" behaviour) $[9,13]$.

Experimental synthesis of clay minerals has been a common practice for years [4]. In particular, syntheses of kaolinite and dickite [14] and sepiolite [15,16]; were achieved with good results. Experimental precipitation of sepiolite by evaporating seawater at earth-surface conditions unravelled that sepiolite can form from solutions whose $\mathrm{pH}$ ranges from 8.2 to 8.5, depending also on the activities of ions and silica; a summary of laboratory synthesis studies dealing with sepiolite, palygorskite and other Mg-clays can be found [8,9].

Authigenic clays can form also by transformation of precursor, detrital minerals in both alkaline lakes and marine basins. This process was termed "neoformation by addition" [6]; the mechanisms involved are still a matter of discussion and several explanations have been proposed [17]. More recently, an update of the subject has been provided [9] pointing out the diffuse boundaries between the mechanisms of epitaxy (precipitation on pre-existing natural surfaces) and topotaxy (transformation and reaction of pre-existing surfaces) as processes leading to formation of authigenic Mg-silicates after detrital clay precursors.

In their seminal study on the occurrence of clays in sandstones, Wilson and Pittman differentiated allogenic (detrital) from authigenic clays and provided a number of criteria for distinguishing the two clay types when observed by either standard microscope petrography or scanning electron microscopy (SEM) [18]. The study included kaolinite and dickite, chlorite, illite, smectite and mixed-layer illite-smectite; dealing with authigenic clays, the authors talked about "neoformed" and "regenerated", the latter formed after precursor minerals. Moreover, some features allow discrimination of neoformed authigenic clays and clays that resulted from transformation of precursors [8]: (a) Neoformed authigenic clays commonly show low REE (rare earth elements) and TTE (transition trace elements) contents, except for $\mathrm{F}$; in contrast, authigenic clays resulting from transformation of a precursor mineral are characterized by low to moderate trace contents. (b) Neoformed authigenic clay deposits usually show absence, or low abundance, of detrital minerals; in contrast, authigenic clay deposits due to transformation are commonly rich in detritals. (c) When observed in thin section and/or by scanning electron microscopy, the textures of the neoformed authigenic clays are clean and show distinct particles; in contrast, transformed clay textures are usually dirty and less well-defined.

\subsection{Magnesian Clays-General Concepts and Types}

Magnesian clays constitute a significant part of the Mg-rich phyllosilicate family, this encompassing also serpentine minerals, phlogopite, Mg-vermiculite and chlinochlore [19]. The magnesian clays mostly include 2:1 clay minerals: talc, kerolite (disordered turbostratic talc) and trioctahedral smectites (stevensite, saponite, hectorite) as well as chain or fibrous clays (sepiolite and palygorskite) (Figure 2). These minerals are rich in magnesium (from 21 to $32 \mathrm{wt} . \% \mathrm{MgO}$; Table 1) except for palygorskite ( $\mathrm{MgO}$ content shows relatively low values ranging 10-14 wt.\%). According to their geochemistry, the magnesian clays can be Al-free Mg-clay minerals, which include kerolite (talc), stevensite and sepiolite and Al-bearing Mg-clay minerals, in the latter case saponite and palygorskite. Mg-clays may also include some mixed layers, that is corrensite (regular interstratification of trioctahedral chlorite with trioctahedral smectite or vermiculite). 


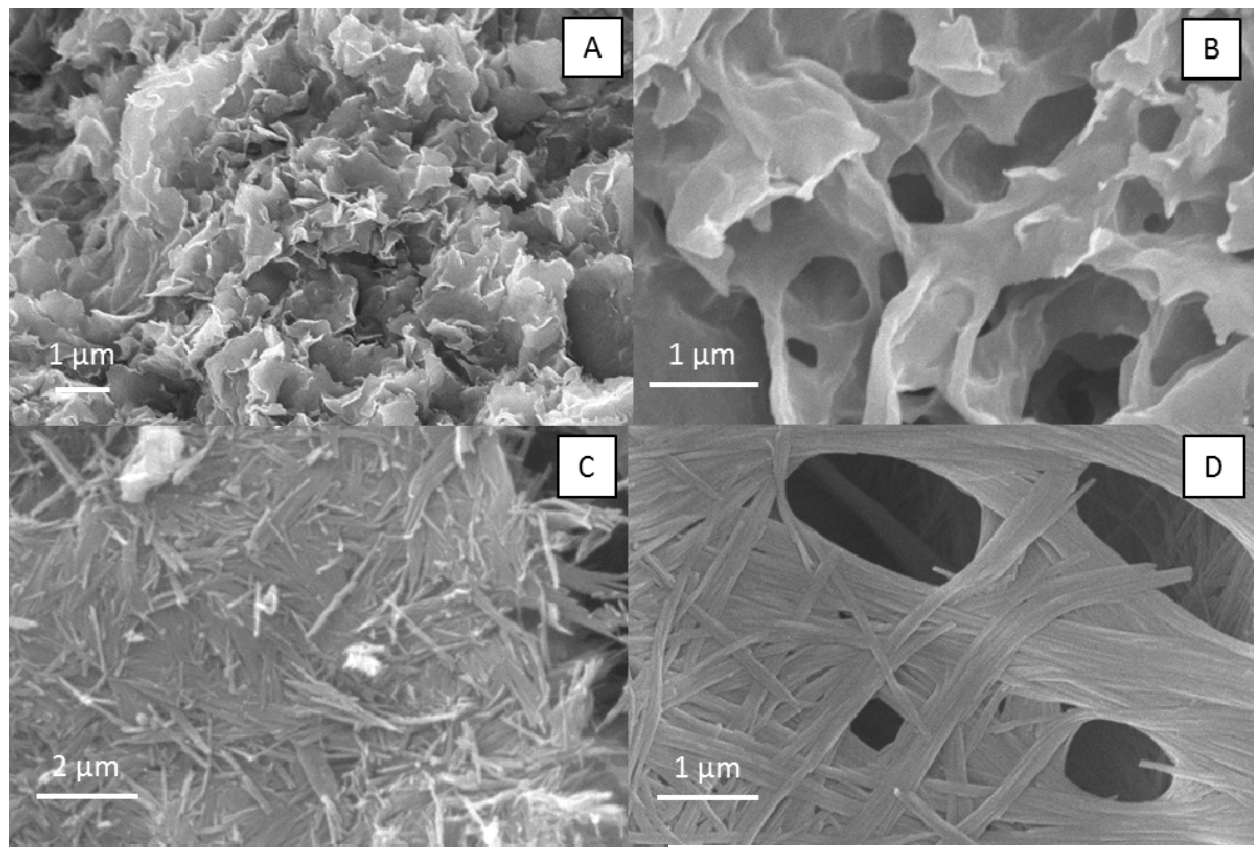

Figure 2. SEM images of Al-bearing and Al-free Mg-clay minerals. (A) Saponite. (B) Stevensite. (C) Palygorskite. (D) Sepiolite.

Table 1. Main magnesian clay minerals and their chemical composition. The box symbol indicates vacancies in the octahedral sheet of stevensite.

\begin{tabular}{cc}
\hline Clay Minerals & Composition \\
\hline \multirow{2}{*}{ Trioctahedral Smectites } & Saponite: $\mathrm{Mg}_{3}\left(\mathrm{Si}_{3,67} \mathrm{Al}_{0,33}\right) \mathrm{O}_{10}(\mathrm{OH})_{2} \mathrm{M}^{+}{ }_{0,33}$ \\
& Hectorite: $\left(\mathrm{Mg}_{2.67} \mathrm{Li}_{0,33}\right) \mathrm{Si}_{4} \mathrm{O}_{10}(\mathrm{OH})_{2} \mathrm{M}^{+}{ }_{0,33}$ \\
& Stevensite: $\left(\mathrm{Mg}_{2.67}{ }^{2,33}\right) \mathrm{Si}_{4} \mathrm{O}_{10}(\mathrm{OH})_{2} \mathrm{M}^{+}{ }_{0,33}$ \\
\hline Palygorskite & $\left(\mathrm{Mg}, \mathrm{Al}, \mathrm{Fe}^{3+}\right)_{5}\left(\mathrm{Si}, \mathrm{Al}_{8} \mathrm{O}_{20}(\mathrm{OH})_{2}\left(\mathrm{OH}_{2}\right)_{4} \cdot 4 \mathrm{H}_{2} \mathrm{O}\right.$ \\
\hline Sepiolite (Loughlinite) & $\mathrm{Mg}_{8} \mathrm{Si}_{12} \mathrm{O}_{30}(\mathrm{OH})_{4}\left(\mathrm{OH}_{2}\right)_{4} \cdot 8 \mathrm{H}_{2} \mathrm{O}$ \\
& $\left(\mathrm{Na}_{4} \mathrm{Mg}_{6} \mathrm{Si}_{12} \mathrm{O}_{30}(\mathrm{OH})_{4}\left(\mathrm{OH}_{2}\right)_{4} \cdot 8 \mathrm{H}_{2} \mathrm{O}\right)$ \\
\hline Kerolite & $\mathrm{Mg}_{3} \mathrm{Si}_{4} \mathrm{O}_{10}(\mathrm{OH})_{2}$ \\
\hline
\end{tabular}

Common MgO content in chemical analysis: Saponite (24-26 wt.\%), stevensite (24-28 wt.\%), kerolite (29-32 wt.\%), sepiolite (21-24 wt.\%), palygorskite (10-14 wt.\%).

Amongst other physico-chemical factors, formation of Mg-clays is mainly controlled by $\mathrm{pH}$ (alkalinity), $\mathrm{PCO}_{2}$ and salinity [20]. Stability relations for hydrous magnesium silicates with respect to solute activities point out that sepiolite, stevensite and kerolite equilibria depend on salinity $(\mathrm{Na})$, $\mathrm{pH}$ and $\mathrm{Mg}$ concentration [7]. High salinity favours the formation of stevensite whilst sepiolite and kerolite are formed under lower saline conditions, with high $\mathrm{Si} / \mathrm{Mg}$ ratio favouring the formation of sepiolite. Likewise, precipitation of kerolite rather than formation of sepiolite are favoured by an increase of $\mathrm{pH}$ and $\mathrm{Mg}$ content in solution running in parallel with a decrease. The metastability of kerolite relative to sepiolite is corroborated experimentally [21]. Provided that aqueous $\mathrm{CO}_{2}$ has a strong effect on $\mathrm{pH}[22,23]$, it plays a significant role in the formation of magnesium silicates under evaporative conditions. Moreover, increasingly $\mathrm{CO}_{2}$ levels could result in dissolution of Mg-silicates [24].

Formation of sepiolite by direct precipitation from silica- and magnesium-rich solutions is the most widely accepted process for this Mg-clay mineral [20,25]. Sepiolite may also form from colloidal silica in Mg-rich environments; the resulting hydrated magnesium silicate precursor constitutes a mineral support that would form sepiolite in periods of desiccation [26-28]. In this respect, if a solution has insignificant or very low aluminium activity $\left(\log \left[\mathrm{aAl}^{3+} /\left(\mathrm{aH}^{+}\right)^{3}\right]<7.5\right)$, direct precipitation of 
sepiolite occurs; by the contrary, precipitation of sepiolite diminishes as the activity ratio increases [29]. Direct sepiolite precipitation is enhanced in very silica-rich $\left(\log \left[\mathrm{aH}_{4} \mathrm{SiO}_{4}\right] \geq-4.75\right)$ solutions. In case of silica-poor solutions, sepiolite requires a higher $\mathrm{pH}$ for its formation than that required by palygorskite. The formation of sepiolite may also result from dissolution of Mg-rich clay minerals such as stevensite, saponite and kerolite. Ideal thermochemical and kinetic conditions for the formation of sepiolite deal with variations in salinity, which force the dissolution-precipitation transformation process [30-35].

A review of the lab synthesis of Mg-smectite, including hectorite, stevensite and saponite, at low temperature and pressure is available [36]. In most experiments, precipitation of nearly single phases commonly with excess of amorphous silica was observed. The neoformed precipitates show low crystallinity, which improved after aging in the aqueous suspension $[37,38]$. Formation of kerolite and/or kerolite-stevensite mixed layers by neoformation has been proposed [30,34,39]). Kerolite displays an extreme layer-stacking disorder, which explains its common colloform texture and supports neoformation from colloidal suspensions [40]. Neoformation of kerolite from gels by mixing of Mg-rich lake water and silica laden groundwater in palustrine environment has been reported [34]; in this study case, mixed layer kerolite-stevensite formed as a consequence of increasing salinity-alkalinity driven mostly by evaporation, which supports statement by B.F. Jones that salinity favours the interstratifications of kerolite-stevensite. This conclusion can be also issued from studies in modern saline-alkaline lakes of South America and Africa [41,42].

Poorly crystalline Mg-rich products obtained by lab synthesis show structural features consistent with kerolite, stevensite and sepiolite [43]. Major controls on the type of synthetic Mg-clay mineral were $\mathrm{pH}$, salinity and $\mathrm{Mg} / \mathrm{Si}$ concentration (see discussion above).

Models for palygorskite formation have been reviewed and discussed by several authors [20,44-46]. Two contrasting genetic models have emerged. Some formation models consider that palygorskite originates from aluminous precursors [25,47], while other models point to palygorskite as a result of direct precipitation from solution $[45,48,49]$. Nowadays, most accepted mechanism for palygorskite formation is transformation by dissolution-precipitation, given the abundance of fine detrital materials supplying aluminium. Local neoformation by direct precipitation may take place under restricted conditions. Phase diagrams show that precipitation of palygorskite can take place only for $\log \left[\mathrm{aAl}^{3+} /\left(\mathrm{aH}^{+}\right)^{3}\right]$ value around 5.5 and a $\log \left[\mathrm{aMg}^{2+} /\left(\mathrm{aH}^{+}\right)^{3}\right]$ value between 11 and 13 [29]. Investigation by means of transmission electron microscopy clearly indicates the existence of a precursor in palygorskite formation [50-53]. Montmorillonite is the commonly proposed precursor phase although beidellite [54], illite [55,56], chlorite [57] and even primary silicates [46] have also been pointed out.

\section{Authigenic Mg-Clay Minerals in Marine and Non-Marine Modern Environments}

Mg-clay minerals are mainly formed in sedimentary environments, although they are also related to hydrothermal processes taking place in continents and deep-sea floor settings [58,59]. The most common Mg-rich clays associated with continental hydrothermal processes are saponite, corrensite and chlorite, their occurrence being controlled by time, temperature and the geochemistry of waters. In submarine hydrothermal systems, the clay mineral assemblages comprise saponite, talc, disordered talc (kerolite), talc-smectite mixed layered, chlorite-smectite mixed layered, corrensite and chlorite. The formation of these minerals is favoured by mixing between seawater (Mg-rich) and hydrothermal fluids as well as by the existence of unconsolidated sediments on the sea floor that may provide a large surface area for hydrothermal interactions.

Most favourable conditions for the formation of Mg-clays on earth surface are found in evaporitic depositional environments, especially where parent rocks are enriched in ferromagnesian minerals. Accordingly, Mg-clays are an important constituent of weathering profiles and soils developed in basic and ultrabasic rocks, especially in arid and semi-arid climates. In these soils, $\mathrm{Al}$ and Fe-smectites, sepiolite and palygorskite are dominant clay minerals (Figure 3). For instance, Mg-smectites and palygorskite are present in modern soils of the Mediterranean region [60]; moreover, smectite clays 
showing swelling behaviour are a common constituent of vertisols developed under dry conditions. Occurrence of palygorskite in argillaceous soils as well as in calcretes is frequent in regions where mean annual rainfall reaches up to $400 \mathrm{~mm}$ and the chemistry of water within the soil profile is saline and/or alkaline $[8,48]$.

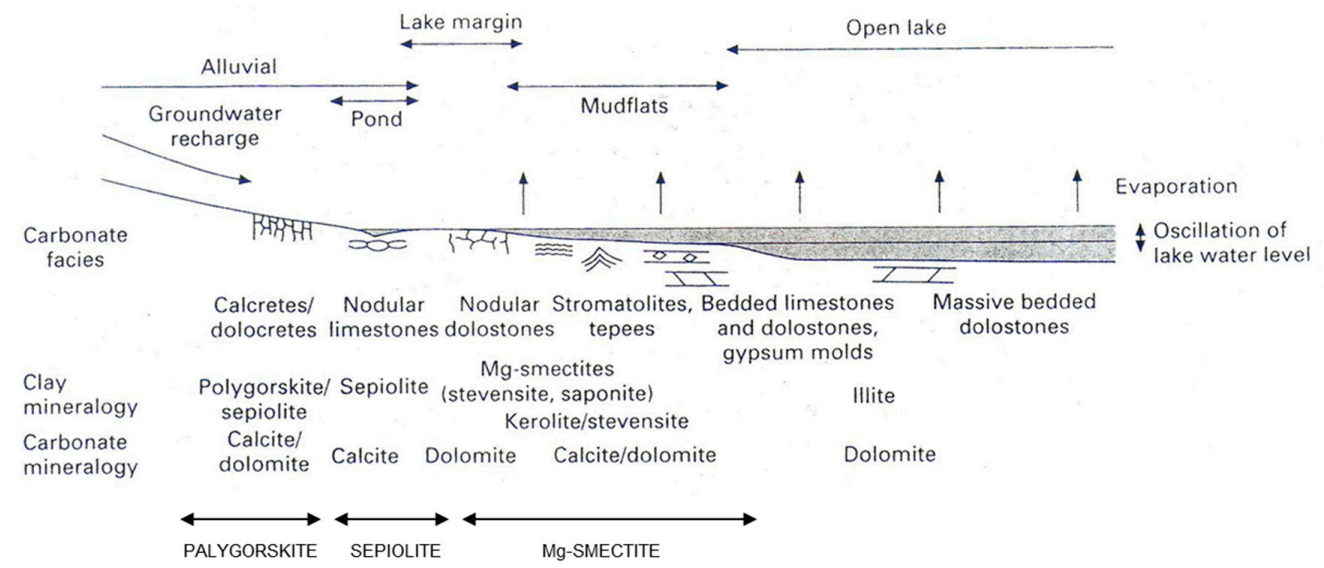

Figure 3. Idealized model showing the paleogeographic distribution of clays (mainly Mg-clays) and carbonate deposits in the Miocene formations of the Madrid Basin (modified from [59]).

Saline lake systems linked to hydrologically closed basins are depositional settings where formation of Mg-clays is highly favoured [61]. Evaporitic conditions occur mainly in lakes developed in underfilled basins [62]. The saline lakes in these basins can be permanent or ephemeral; in the latter case, the term "playa" is used. Solutes in the lakes have a long residence time and usually contain extremely high values of total dissolved solids (TDS), reaching up to $500 \mathrm{~g} / \mathrm{L}$.

Saline lakes develop in arid or semi-arid regions (usually hot but also cold regions) where the rate of evaporation is equal to or exceeds the input from rivers and rain and the resulting brine becomes more and more concentrated with time. Brine composition depends on the lithologies that are leached in the catchment area of the lakes. Obviously, formation of Mg-clays will be favoured where source rocks are enriched in Mg-rich minerals, for example ferromagnesian silicates, Mg-rich carbonates and so forth.

In both salt lakes and playas clays (illite, kaolinite, chlorite, dioctahedral smectite, mixed layered clays) are mostly detrital, reflecting the compositions of the catchment argillaceous formations as well as the intensity of weathering processes in the drainage areas. Depending on the magnitude of detrital clastic input into the lake basins, formation of authigenic clays can be favoured or swamped [63]. Regions with rapid deposition of clays tend to be not suitable; in contrast, low sedimentation areas, especially the marginal areas of both playas and saline lakes, the transformation of precursor clays into new clay minerals is more effective. Clay neoformation of sepiolite and Mg-smectites is also recognized in interdunal depressions and ponds developed in mudflat environments.

Case studies of saline lakes where Mg-clays are currently formed are, for instance, the Great Salt Lake in Utah [64], Lake Abert in Oregon [65] and several East African recent lake basins [7,23,66]. In Great Salt Lake, a principal mechanism for incorporation of magnesium and silica in sediments is the formation of silicate interstratifications in a pre-existing 2:1 phyllosilicate [67]. The purity of the resulting magnesium silicate depends on the relative amount of detrital versus precipitated clay, which confirmed earlier conclusions from studies conducted in Lake Abert [68].

A common feature of saline lakes is that the water chemistry can reach high supersaturation according to rapid changes in the lake environment; high supersaturation usually results in homogeneous nucleation leading to Mg-silicate formation [9]. Tosca pointed out Lake Chad and some nearest lakes as a good example for neoformation of Mg-clay minerals on the basis of previous studies by French researchers [42,69]. Precipitation of stevensite took place by evaporation of lake waters in the region. Also dealing with African lakes, several case studies of formation of authigenic Mg-clays have 
been provided [7,66,70-72]. A major conclusion is that authigenic clay minerals are likely to form in those lake settings because of the very high alkalinities and high silica levels ( $>100 \mathrm{mg} / \mathrm{L})$; under such chemical conditions, favoured by drainage lake areas composed of volcanic rocks, not much $\mathrm{Mg}$ is required to precipitate $\mathrm{Mg}$-rich smectite even sepiolite $[7,66])$. Both neoformation and transformation of previously accumulated detrital clays can act as processes leading to the formation of authigenic Mg-clays in the lakes. One outstanding evidence derived from the aforementioned case studies of modern lake basins is that clay mineral occurrences, in particular those of the authigenic Mg-clay minerals match well the "clay zoning" hypothesis and sedimentary model proposed by Millot [6]. This model shows that detrital clay inputs, mainly kaolinite, illite, chlorite and Al-rich smectite, in the margins of saline lake basins transitionally pass into fibrous clays (palygorskite, sepiolite) that precipitate in the centre of the lakes.

In modern marine environments, formation of Mg-clays is not so common as in the continental realm. Pore water evidence for the formation of authigenic Mg-clays is ubiquitous in the marine environment extending from the continental shelves to the abyssal ocean. The diagenetic processes lead to disseminated authigenic clay (mostly Al-silicate) with concentrations of a few wt.\% of the bulk sediment so that authigenic clay deposits are rarely formed in those settings [73,74]. In contrast, physico-chemical conditions of some peri-marine regions favour their formation [75]. In these areas, alkaline, saline waters can result in Mg-clay formation, especially fibrous clays (sepiolite, palygorskite). Salinas Ometepec in Baja California is indicated as an appropriate coastal marine environment where authigenic K-rich Mg-smectite is currently taking place [61]; the process is mainly due to dissolution of detrital aluminosilicates concurrent to selective dissolution of $\mathrm{K}$ - and $\mathrm{Mg}$-salts. In addition to these occurrences, suitable conditions for the formation of authigenic Mg-clays could develop in sea sediments of the past (see further section on occurrences of Mg-clays in ancient deposits).

\section{Authigenic Mg-Clay Minerals in Ancient Sedimentary and Non-Sedimentary Geological Formations}

\subsection{Mg-Clay Deposits in Sedimentary Environments}

Occurrence of Mg-clays in sediments, locally forming deposits of economic interest, is common [76-78]. Most of the currently exploited sepiolite and Mg-smectite deposits occur in continental, mainly Neogene formations, although peri-marine Mg-clays (e.g., palygorskite) form some important economic deposits (Figure 5). The Neogene formations include the largest sepiolite resources located in central Spain (Madrid Basin), the increasingly important Turkish deposits and those spreading out in western USA, Morocco, China and other localities [75]. Sepiolite is a significant component of ancient lake deposits that were characterized by saline alkaline waters. The large palygorskite deposits of Meigs-Attapulgus-Quincy in USA and Allau Kagne-Thies in Senegal were related to peri-marine environments. Table 2 shows a list of some major Mg-clay deposits with indication of mineralogical assemblages, depositional environments and origin of the clay minerals.

\subsubsection{Peri-Marine Palygorskite Deposits}

Large palygorskite deposits occur in the Meigs-Attapulgus-Quincy district extended in Georgia and Florida [75]. Therein, the stratigraphic succession is included in the Hawthorn Formation and is composed of clastics (sand, silt and clay) as well as by some phosphates (apatite), carbonates (dolomite, calcite) and chert (Figure 4A). Formation of the palygorskite deposits took place in coastal marine environments (brackish lagoon and tidal areas) developed at the Lower Miocene-Middle Miocene boundary [79]. Two palygorskite clay beds ranging 1-5 $\mathrm{m}$ thickness are exploited in south Florida; palygorskite content in these beds reaches up to $70-80 \mathrm{wt} . \%$ or even exceeds it. Palygorskite is mixed with montmorillonite, sepiolite, quartz, calcite and apatite. In Georgia, the palygorskite clay beds reach up to $18 \mathrm{~m}$ in thickness although the palygorskite content is lower than in the Florida deposit, ranging from 30 to $60 \mathrm{wt} . \%$. Formation of the palygorskite deposit in Georgia has been 
interpreted as a result of the alteration of montmorillonite in shallow coastal lagoons [47]. Salinity, $\mathrm{pH}$ and temperature were critical factors in the formation of the fibrous clay mineral, which has been confirmed by further studies $[53,80]$.

Table 2. Most important magnesian clay deposits occurring in Cenozoic continental formations. (Sep. Sepiolite. Sap. Saponite. Tlc/Stv. Kerolite-stevensite mixed layer. Stv. Stevensite. Plg. Palygorskite. Ilt. Illite. Kln. Kaolinite. Chl. Chlorite. Sme. Smectite. Dol. Dolomite. Qz. Quartz. Fsp. Feldspars. Cal. Calcite. Opl. Opal. Brt. Baryte. Zeo. Zeolites. Gp. Gypsum. Clt. Cristobalite. Ms. Muscovite. Ilt/Sme. Illite-smectite mixed layers.

\begin{tabular}{|c|c|c|c|}
\hline Deposit/AGE & Mineralogical Assemblage & Environment & Origin \\
\hline $\begin{array}{l}\text { Eskisehir (Turkey) } \\
\text { (Miocene) }\end{array}$ & Sep-(Dol-Qz-Ilt-Fsp) & Lacustrine & Neoformation Diagenetic \\
\hline $\begin{array}{c}\text { Amargosa (USA) } \\
\text { (Pliocene-Pleistocene) }\end{array}$ & Sep-Sap-(Ilt-Stv / Tlc-Dol-Cal) & Lacustrine (playa) & Neoformation Diagenetic \\
\hline $\begin{array}{l}\text { Vicálvaro-Yunclillos } \\
\text { (Spain) (Miocene) }\end{array}$ & Sep-(Sap-Stv-Ilt-Cal-Dol-Qz-Fsp) & Lacustrine/alluvial & Neoformation Diagenetic \\
\hline $\begin{array}{c}\text { Batallones } \\
\text { (Spain) (Miocene) }\end{array}$ & Sep-(Plg-Sap-Ilt-Qz-Fsp-Opl-Cal) & Palustrine & Neoformation Diagenetic \\
\hline $\begin{array}{l}\text { Cabañas-Yuncos } \\
\text { (Spain) (Miocene) }\end{array}$ & Sap-(Ilt-Sep-Kln-Qz-Fsp-Dol-Cal-Stv/Tlc) & Lacustrine/alluvial & Diagenetic Neoformation \\
\hline $\begin{array}{c}\text { Magan } \\
\text { (Spain) (Miocene) }\end{array}$ & Sap-(Ilt-Sep-Stv-Kln-Qz-Fsp-Cal-Brt) & $\begin{array}{l}\text { Lacustrine } \\
\text { (mudflat) }\end{array}$ & Diagenetic Neoformation \\
\hline $\begin{array}{c}\text { Esquivias } \\
\text { (Spain) (Miocene) }\end{array}$ & Tlc/Stv-(Sep-Sap-Ilt-Qz-Cal-Dol-Zeo) & $\begin{array}{l}\text { Lacustrine } \\
\text { (mudflat) }\end{array}$ & Neoformation Diagenetic \\
\hline $\begin{array}{c}\text { Jbel Rhassoul } \\
\text { (Morocco) (Miocene) }\end{array}$ & Stv-(Sep-Dol-Qz-Gp-Clt) & Lacustrine & Diagenetic \\
\hline $\begin{array}{c}\text { Guanshan } \\
\text { (China) (Miocene) }\end{array}$ & Plg-(Sme(Al)-Qz-Sep-Ms-Dol) & $\begin{array}{c}\text { Lacustrine } \\
\text { (alteration profile) }\end{array}$ & Diagenetic (basaltic ash) \\
\hline $\begin{array}{c}\text { Bercimuel } \\
\text { (Spain) (Miocene) }\end{array}$ & Plg-(Ilt-Qz-Kln-Sme(Al)-Ilt/Sme) & Alluvial & $\begin{array}{c}\text { Diagenetic } \\
\text { (Al-smectite) }\end{array}$ \\
\hline $\begin{array}{l}\text { Torrejón el Rubio } \\
\text { (Spain) (Paleogene) }\end{array}$ & Plg-(Ilt-Sep-Chl-Dol-Sap-Qz-Fsp) & $\begin{array}{l}\text { Lacustrine-palustrine } \\
\text { (alteration profile) }\end{array}$ & $\begin{array}{l}\text { Diagenetic } \\
\text { (chlorite) }\end{array}$ \\
\hline
\end{tabular}

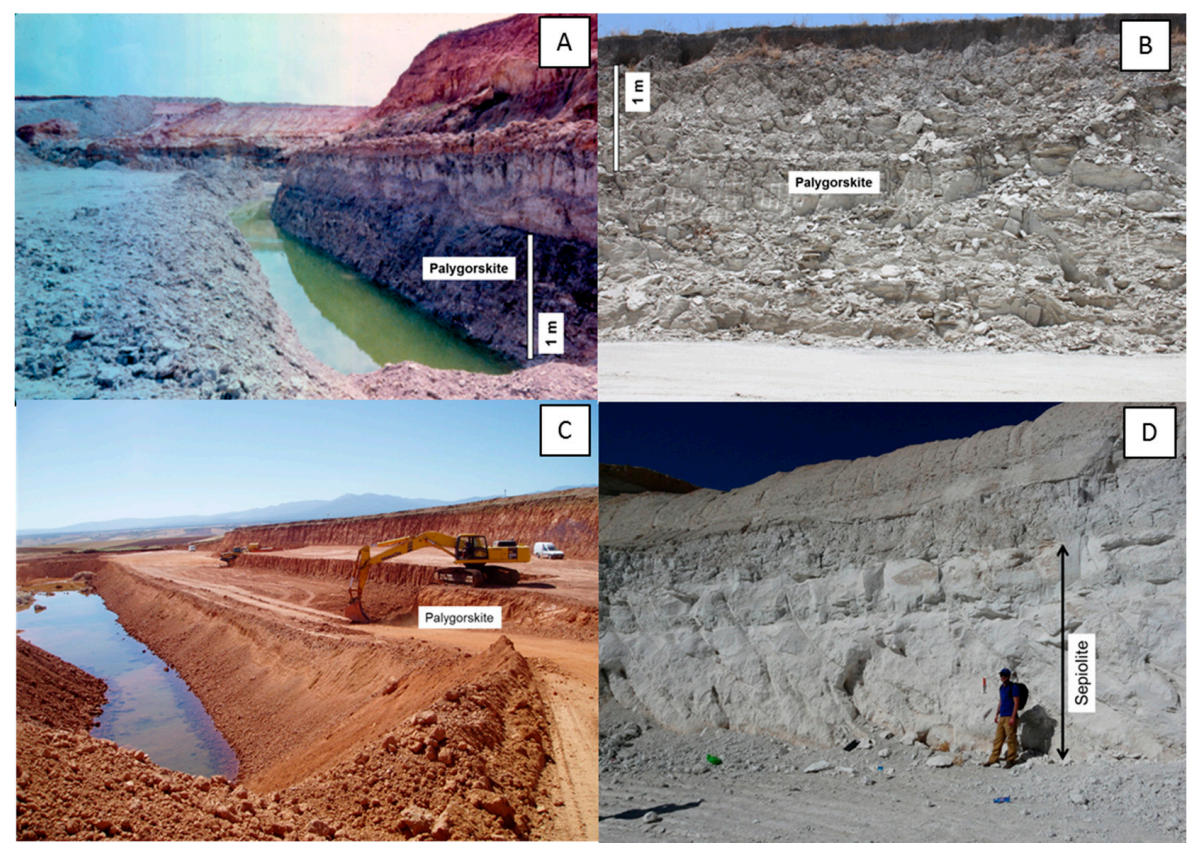

Figure 4. Quarry fronts from different Mg-clay deposits. (A) Florida-Georgia palygorskite deposit at Quincy (USA). (B) Thies-Allou Kagne palygorskite deposit (Senegal). (C) Bercimuel palygorskite deposit (Duero Basin, Spain). (D) Bedded sepiolite in the Eskisehir deposit (Turkey). 
The Paleogene Allou Kagne-Thies palygorskite deposit is located in the Senegal-Mauritania (Africa) Basin [75]. The palygorskite beds occurs associated with underlying clayey marlstone and limestone beds that pass upward to a glauconitic phosphate bed that in turn is overlain by massive to laminated clays containing palygorskite (Figure 4B). Two beds can be distinguished in this palygorskite-rich unit: the lower, reaching up to $8 \mathrm{~m}$ in thickness, is massive and carbonate-rich (up to $30 \mathrm{wt}$.\% carbonates) whilst the upper bed contains almost pure palygorskite displaying horizontal lamination with local chert inserts. Interbedded in these units, there is a thin interval $(0.1 \mathrm{~m})$ of silicified and carbonated sandstone, which is used as a guide level at a regional scale. The formation of the palygorskite deposits took place in an epicontinental marine environment. Palygorskite is the major component of the deposits with minor amount of quartz, dolomite, chert (microcrystalline quartz) and sepiolite. Neoformation is inferred as a main mechanism of palygorskite formation in the Senegal deposit; moreover, the coexistence of Mg-rich palygorskite and Al-rich sepiolite in some beds could also indicate epitactic growth [81].

\subsubsection{Continental Palygorskite Deposits}

The Guanshan palygorskite deposit, the most important in China, is located in the Anhui province. The deposit is related to volcanic rocks and occurs as a stratigraphic level at the top of the Upper Member of the Huaguoshan Formation [82]. The age of this formation is Miocene and the economic deposit is interbedded in an 18 to $54 \mathrm{~m}$-thick succession of basalts and volcanic ashes. Palygorskite occurs associated with the volcanic ash beds, which were accumulated in a lake environment. The palygorskite deposit ranges from 3 to $6 \mathrm{~m}$ in thickness and content in palygorskite ranges from $55 \mathrm{wt} . \%$ to more than $90 \mathrm{wt} . \%$, with minor quartz content $(<10 \mathrm{wt} . \%)$ and traces of sepiolite, smectite, opal, mica and dolomite. The palygorskite in the Guanshan deposit is Fe-rich exhibiting short length fibres. Most reliable model of formation of the Guanshan palygorskite deals with "in situ" transformation of volcanic ash, both for palygorskite and the associated smectite [82]. The detailed mechanism of the palygorskite origin from smectite transformation has been reported [83].

The Ventzia Basin, located near Grevena (Macedonia, northern Greece), contains palygorskite and saponite-rich clays of Plio-Pleistocene age [84]. Palygorskite is present in 10 to $18 \mathrm{~m}$-thick beds showing $60-90 \%$ purity. In this deposit, palygorskite formed through the diagenetic transformation of saponite-rich sands derived from the weathering of ultramafic rocks (Vourinos Ophiolitic Complex). This Mg-rich source would justify the high iron content (up to $11 \mathrm{wt} . \% \mathrm{Fe}_{2} \mathrm{O}_{3}$ ) of the palygorskite [85].

In Spain, the most important palygorskite deposit is located in the locality of Bercimuel, south of the Neogene Duero Basin [86]. In this deposit, palygorskite occurs associated with detrital sediments that were deposited in alluvial fan systems changing laterally into a lake environment. The detrital clay unit consists of two beds ranging 1-1.5 $\mathrm{m}$ in thickness; the average palygorskite content of these beds reaches up to $60-70 \mathrm{wt} . \%$. The lower bed is white in colour and contains $70 \mathrm{wt} . \%$ palygorskite and $30 \mathrm{wt} . \%$ illite whereas the upper bed is reddish in colour and is composed of $30 \mathrm{wt} . \%$ palygorskite $-70 \mathrm{wt} . \%$ illite (Figure 4C). Palygorskite in both beds occurs associated with inherited quartz, illite and kaolinite as well as with smectites and interstratified minerals (smectite-illite) resulting from transformation of the detrital clays. The most reliable model of formation of the Bercimuel palygorskite deals with development of a series of post-sedimentary processes that transformed the original sediment of the alluvial fan, mainly consisting of clayey quartz silts, illite, feldspars and kaolinite. There is strong textural evidence (SEM analysis) of the transformation of Al-smectite into palygorskite [52].

Other palygorskite deposits formed in continental environments include those exploited in Guatemala, Ukraine (Cherkassy), India (Andra Pradesh and Gujarat) and Australia (Ipswich, Garford paleochannel-Lake Frome area and Lake Nerramyne) [75]. 


\subsection{Continental Mg-Smectite and Sepiolite Deposits}

The middle Miocene formations of the Madrid Basin, an intracratonic sub-basin of the major Tagus Basin in the centre of the Iberian Peninsula, contain the most complete clay mineral association recognized in ancient evaporite lake systems in Spain [8]. Fibrous clay minerals (sepiolite and minor palygorskite) occur associated with stevensite, saponite, kerolite-stevensite, which is quite clearly recognized in the transition zone between distal alluvial fan and lake-margin environments (Figure 5). The Mg-clays form large deposits of Mg-bentonite, bleaching earths (kerolite/stevensite mixed layers) and high purity sepiolite $[8,87,88]$. The Mg-clay deposits occur in several lithofacies spreading out in the northwest and south-southwest parts of the basin [88]. Clays showing higher Mg content occur mainly in marginal basin locations rather than in the basin centre. Saponite is predominant in the Mg-bentonite deposits, which occur in both marginal lacustrine deposits [89] and distal alluvial fan facies [90]. The existence of stevensite associated with sepiolite has been reported [91] and later studies identified stevensite interstratified with kerolite [92]. The sepiolite deposits formed mainly associated with alluvial fan facies (Vallecas-Vicálvaro-Cabañas deposits), palustrine conditions in marginal lake environments (Cerro de los Batallones deposit) and associated with other Mg-clays in mud-flat facies (Esquivias-Magán deposits). Presence of palygorskite, alone or associated with sepiolite, has been also reported $[8,93,94]$.

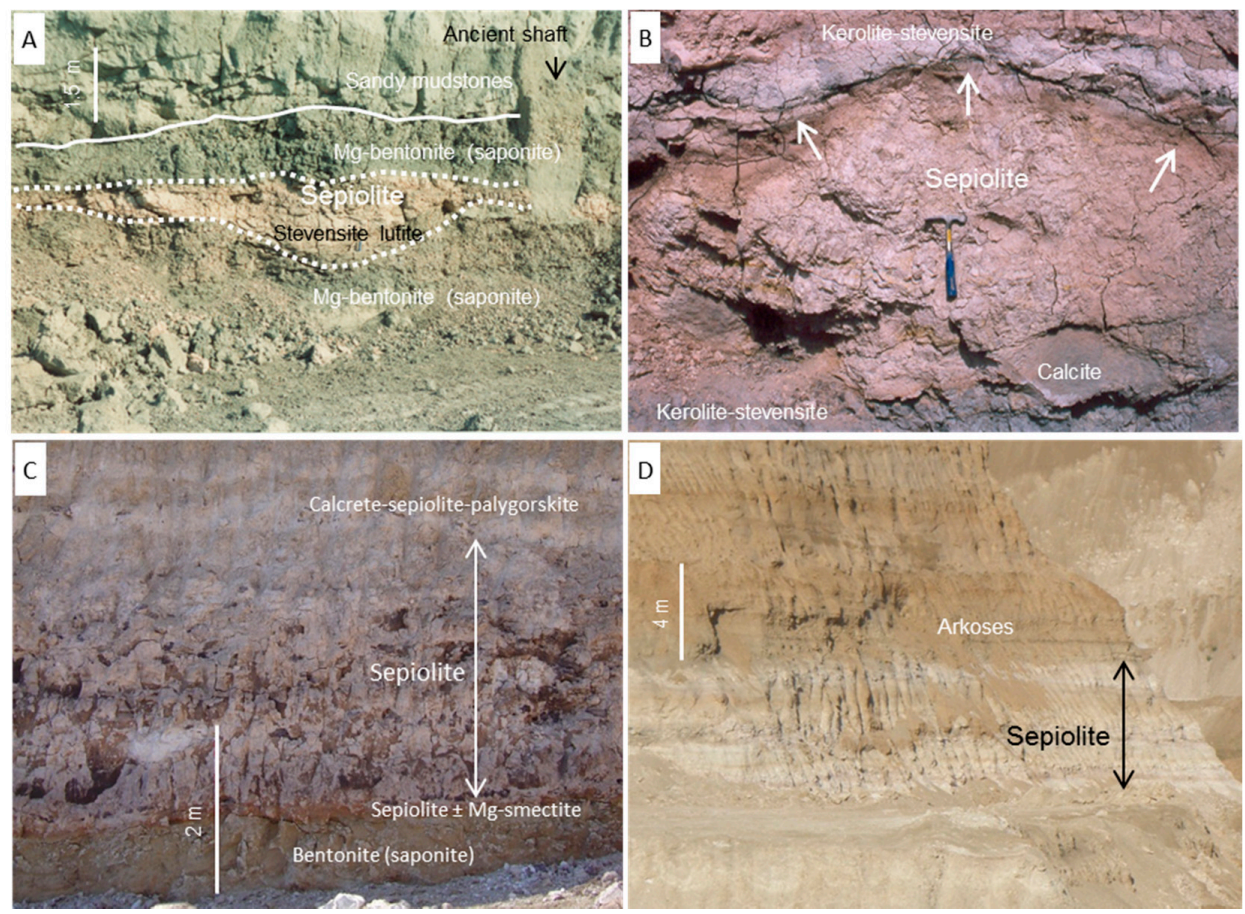

Figure 5. Representative field photographs of Mg-clay assemblages in different environments of the Madrid Basin. (A) Mud flat lithofacies (saponite-stevensite-sepiolite). (B) Mud flat lithofacies (kerolite-stevensite mixed layers-sepiolite). (C) Palustrine lithofacies (saponite-sepiolite-palygorskite). (D) Alluvial fan lithofacies (sepiolite).

The most representative sepiolite deposit is located in the Vallecas-Vicálvaro area close to the city of Madrid. In this location, the sepiolite occurs mostly in two stratigraphic levels that are capped by arkosic sandstones of distal alluvial-fan facies (Figure 6D). Depositional conditions for the formation of the sepiolite dealt mainly with flooding events taking place over the fringe facies accumulated between distal alluvial fans and the mudflats of a saline-alkaline lake. Moreover, sepiolite also formed in sediments of the alluvial fringe that were associated with calcretes [95]. The sepiolite occurring at the lower lacustrine sequence is formed by a single 1-5 m-thick sepiolite bed showing a lenticular morphology with intercalation of dolomitic carbonates, $\mathrm{Mg}$-smectite clays and chert, the latter being 
more developed in the most marginal facies. The sepiolite of the upper lacustrine sequence is composed of a basal reddish bed of laminated sepiolite rich in detrital minerals (quartz and feldspar). As in the lower lacustrine sequence, the sepiolite bed shows a lens-like morphology with carbonate and chert intercalations at its margins. The bed can be separated into two exploitable layers that as a whole reach up to $10 \mathrm{~m}$ in thickness. The formation of the sepiolite deposit of Vicálvaro can be explained by a primary mechanism of neoformation by precipitation. However, detailed analysis of the sepiolite containing smectite phases in the lower lacustrine sequence points to a mixture of stevensite, saponite and a micaceous mineral; in this case sepiolite should be interpreted as a result of diagenetic alteration of the Mg-rich smectites [96].

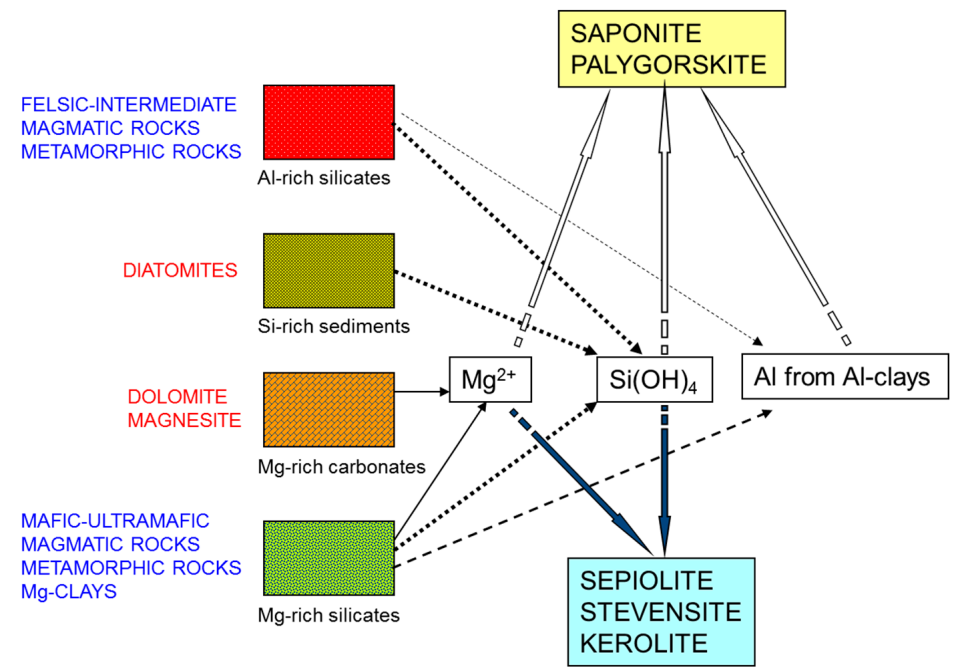

Figure 6. Relationships between types of parent rocks rich in magnesium and silica and the resulting Mg-clays in the sedimentary environment (after [59]).

Because of the abundant ophiolites occurring in the Anatolian Peninsula, many regions of Turkey are favourable for the formation of $\mathrm{Mg}$-rich deposits. The high magnesium content of the ophiolites, which were emplaced after the late Cretaceous, constrained the formation of Mg-rich clays and carbonates in the Turkish hinterland throughout the Cenozoic. Most of the Mg-rich lacustrine deposits occur in western and central-eastern Anatolia, where at least nine continental basins containing Mg-rich authigenic clays have been studied [97]. Common lithofacies associations in the basins consist of alluvial and fluvial deposits in the basin margins that interfinger with sandy claystone, claystone and marls, clayey dolomite and carbonate deposits, the latter ones being dominated by dolomite with local occurrence of magnesite. Volcanic tuffites occur usually interbedded with the clay, marlstone and carbonate deposits; the presence of the tuffites underscores reliable influence of the volcanism leading to alkaline hydrochemical conditions throughout the several evolutionary stages recorded in the basins. The Yenidogan sepiolite deposit, located near the town of Eskisehir, is the most important deposit in the Neogene Eskisehir Basin [98] (Figure 4D). Three lithological associations were distinguished in the basin; the sepiolite occurs in two beds cropping out in the upper levels of a Pliocene dolostone a dolomite marlstone sequence. The lower, $3 \mathrm{~m}$-thick sepiolite bed is formed of sepiolite and dolomitic sepiolite. The upper, up to $10 \mathrm{~m}$-thick sepiolite bed shows a broad lateral extension and it is formed by an alternation of sepiolite and sepiolite-rich layers and lenses. The sepiolite content is high, up to $90 \mathrm{wt} . \%$ and is accompanied by quartz, feldspar, illite and grains of pumice. Moreover, dolomitic sepiolite is particularly abundant in the upper sepiolite bed but its content does not exceed $50 \mathrm{wt} . \%$. The general formation model of sepiolite in the Anatolian basins points out to a paleoenvironmental pattern of shallow margins of alkaline lakes where ephemeral flooding events and wetlands (marshes) favoured direct precipitation of sepiolite from the lake waters. Besides this process, diagenetic modification of clays by solutions circulating through the intergranular porosity 
and along desiccation cracks could be a reliable mechanism of sepiolite formation. Whichever the process, the primary source of $\mathrm{Mg}$ would have been the weathering of ultramafic rocks (serpentinite), common in the basement.

In Morocco, Mg-rich clays of Mio-Pliocene age occur in Jbel Rhassoul. These clays are made up of neoformed clay minerals (interstratified illite-smectite, palygorskite, stevensite and sepiolite) and subordinated detrital clay minerals (phengite, illite and chlorite) $[25,99,100]$. Stevensite is exploited in clay lenses named locally "rhassoul" that show brown colour and soapy appearance and are used as fuller's earth. The stevensite deposits are always associated with lacustrine facies. The facies association includes dolostone (occasionally with gypsum or chert), carbonaceous clays and green clays. Based on the textural relationship among stevensite lens, dolomitic beds and chert nodules, a diagenetic origin for the Mg-smectite was proposed [101]; stevensite formed diagenetically in a perennial lake under wet climatic conditions favouring the dissolution of dolomite and the creation of a silica-rich environment.

Other sepiolite or Mg-smectite deposits formed in continental environments include the sepiolite and saponite deposit of the Amargosa Desert, in California-Nevada, USA [31,102], the Amboseli sepiolite deposit in Kenya and Tanzania [39,71] and the El Bur sepiolite deposit in Somalia [103].

\subsection{Mg-Clay Occurrence in Ancient Non-Sedimentary Environments}

In addition to the above described sedimentary environments, Mg-rich clays occur locally related to hydrothermal processes in continents and deep-sea floor settings (basalts and ophiolites). Usually the formation of ancient authigenic Mg-clays took place in fossil and active geothermal fields showing high variability in temperature, composition and $\mathrm{pH}$ of solutions and fluid/rock ratios [58].

Saponite, corrensite and chorite are the most typical Mg-rich clay minerals associated with continental hydrothermal processes [104]. Regarding corrensite, time and temperature are significant parameters controlling its formation whereas short-term processes, for example alteration in hydrothermal veins, cooling of lava flows in presence of seawater, may constrain either the formation of saponite or the assemblage chlorite-smectite random mixed layered clay and chlorite [58]. The transformation of saponite into chlorite in active thermal fields seems to take place discontinuously; in that case, the reaction sequence is as follows: randomly mixed layered chlorite-smectite (80-100\% saponite) $\rightarrow$ corrensite (40-50\% saponite) $\rightarrow$ swelling chlorite (0-15\% saponite) [104,105].

In submarine hydrothermal systems the most common Mg-clays are saponite, talc, disordered talc (kerolite), talc-smectite mixed layered, chlorite-smectite mixed layered, corrensite and chlorite [106-113]. In this setting, the formation of Mg-rich clay minerals is facilitated by mixing between seawater, which acts as a source for magnesium and hydrothermal fluids. This process is more effective because de presence of unconsolidated seafloor sediments, which provide a large surface area for hydrothermal interactions [108,114,115]. Thus, occurrence of associated talc, mixed-layered kerolite-smectite, Mg-smectite, mixed-layered chlorite-smectite and chlorite was observed in peridotite-hosted and basalt-hosted rocks [110]. In this specific geological context, talc and kerolite-smectite precipitated from high temperature fluids $\left(>250^{\circ} \mathrm{C}\right)$ in chimneys and massive sulphide mounds, as well as on the sediment surface and in open cracks near the seafloor surface. $\mathrm{Mg}$-smectite formed deep in the sediment at moderate temperatures $\left(200-250{ }^{\circ} \mathrm{C}\right)$ whilst chlorite and chlorite-smectite formed at lower temperatures $\left(150-200^{\circ} \mathrm{C}\right)$ in the altered sediment matrix around the hydrothermal mounds.

Occurrence of hydrothermal sepiolite in volcanic rocks and serpentinites has been also reported [116,117]. Variations in temperature and Mg-concentration of hydrothermal solutions can result in either the formation of talc, which is achieved at higher temperature and Mg-concentration, or sepiolite (achieved at lower temperature and Mg-concentration). Hydrothermal sepiolite has been found both in volcanic-hosted and serpentinite-hosted settings in Turkey; therein, the formation model for sepiolite includes hydrothermal transformation of magnesite, dolomite and/or serpentine [118,119]. 


\section{Geochemical Pathways for Mg-Clay Minerals Formation}

The geochemical pathways of Mg-clays formation derive of the interaction between the lithological characteristics of the parent area, which supply $\mathrm{Si}(\mathrm{OH})_{4}, \mathrm{Mg}^{2+}$ and Al-phases and the hydrochemistry of the runoff, lake water and groundwater $[78,120]$. Water chemistry variations according to different depositional systems, especially where evaporative conditions are dominant, usually represent major constrain for both the primary depositional and early diagenetic mineral assemblages [72].

The types of Mg-clay minerals that will be formed in a lake are largely influenced by the lithologies of the catchment areas surrounding the lake, which control water chemistry [121], as well as by the salinity and alkalinity of the lake water and the detrital input into the lake basin $[23,66]$. Several specific rock-forming minerals provide ions and other elements for proper formation of Mg-clays (Figure 6). Source for magnesium is directly related to Mg-rich minerals such as pyroxene, amphibole, olivine, serpentine and chlorite, which are common in magmatic and metamorphic rocks, as well as dolomite, magnesite, even magnesian clays in sedimentary rocks. Regarding silica supply, many igneous and metamorphic rocks and some Si-rich sedimentary rocks, for example diatomite, are excellent sources for that component.

The accumulation of authigenic Mg-clay minerals gives place to mudstone with alkaline surface and pore waters and where dissolved $\mathrm{Mg}^{2+}$ is present, aqueous $\mathrm{Si}(\mathrm{OH})_{4}$ concentration is high and detrital input is low or absent. Neoformation of sepiolite, kerolite and stevensite under these conditions is favoured. Supersaturation is controlled by evaporation, mixing of waters, $\mathrm{CO}_{2}$ degassing and biological activity [9].

Formation of Mg-smectite and/or palygorskite is more likely accomplished where Al-rich detrital clay minerals are available. In that case, precipitation on pre-existing surfaces (surface precipitation or epitaxy) and/or the transformation and reaction of pre-existing surfaces (topotaxy) take place [9]. Presence of foreign surfaces as those of detrital clay minerals account for the formation of Mg-silicates as they contribute to lowering of the interfacial energy required for nucleation; biological surfaces and silica also produce a similar positive effect for the formation of Mg-silicates.

The well-known Mg-clays deposits occurring in the Madrid Basin provide a sound basis to differentiate three main geochemical pathways that neatly contribute to explain the formation of Mg-clay minerals [120]. Major factors involved in the geochemical pathways are: (i) detrital input and (ii) runoff, lake water and groundwater hydrochemistry (Figure 7).

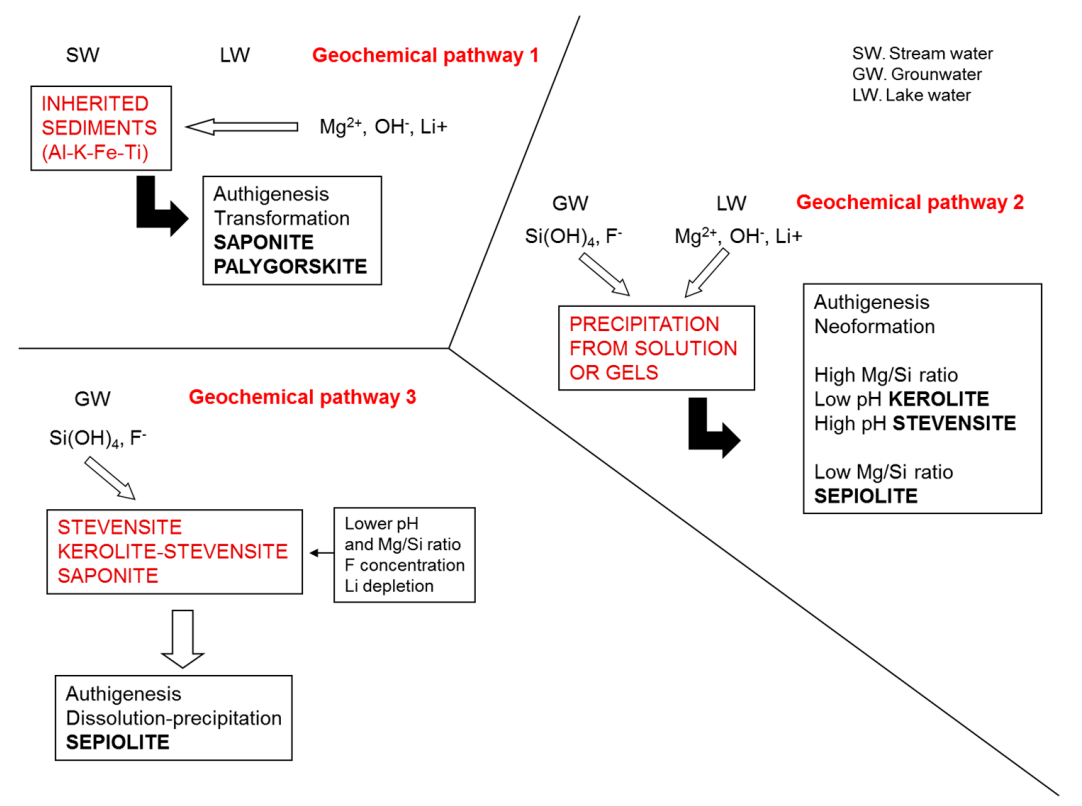

Figure 7. Sketch showing the three main geochemical pathways explaining the formation of the several types of Al-free and Al-bearing magnesian clays (modified from [120] see discussion in text). 


\subsection{Pathway 1}

Geochemical pathway 1 explains the formation of Al-bearing Mg-clays (Figure 7). A schematic sedimentary model for the formation of palygorskite and saponite is shown in Figure 8 . The transformation of Al-bearing clays into palygorskite and/or saponite can take place close to parent rocks that supply $\mathrm{Mg}^{2+}, \mathrm{Si}(\mathrm{OH})_{4}$ and Al-rich colloids; moreover, it can be also related to marginal alluvial-palustrine-lacustrine environments [8] where three water types (runoff, lake water and groundwater) are present. The rocky substrate of the parent area is critical in order to justify inputs of $\mathrm{Mg}$ or Si (Figure 6). Silica input can derive from almost any type of magmatic rock, particularly those with a felsic composition, from silica-rich metamorphic rocks, and/or from siliciclastic, even biogenic (diatomite) sedimentary rocks. Any type of rock containing Mg-rich minerals, that is magmatic rocks such as basalt, gabbro, peridotite, metamorphic rocks, for instance slate and serpentinite and sedimentary rocks such as dolomite, magnesite and magnesian clays, can be source for $\mathrm{Mg}$. $\mathrm{Si}$ and $\mathrm{Mg}$ released in the parent rock areas may travel variable distances and then be accumulated in the lake basins. Except for very alkaline $\mathrm{pH}$ conditions, $\mathrm{Al}$ will tend be less mobile because of its low solubility and thus it will remain in the vicinity of the parent rock; alternatively, Al may be transported as in the form of aluminous clay particles or colloids.

Weathering processes affecting the parent rock area usually lead to the formation of aluminous clay minerals and the release of $\mathrm{Mg}$ and $\mathrm{Si}$. This would favour palygorskite formation, mainly by transformation, in lake environments. Detrital aluminous clay minerals are common in distal alluvial fan facies. Long subaerial exposure periods typical of that depositional sub-environment favour the formation of palygorskite after inherited aluminous clays; this process also produces calcite precipitation. In areas nearby the lake, in particular mudflats where water tends to be more alkaline, the transformation of aluminous smectite into saponite would be favoured instead of forming palygorskite.

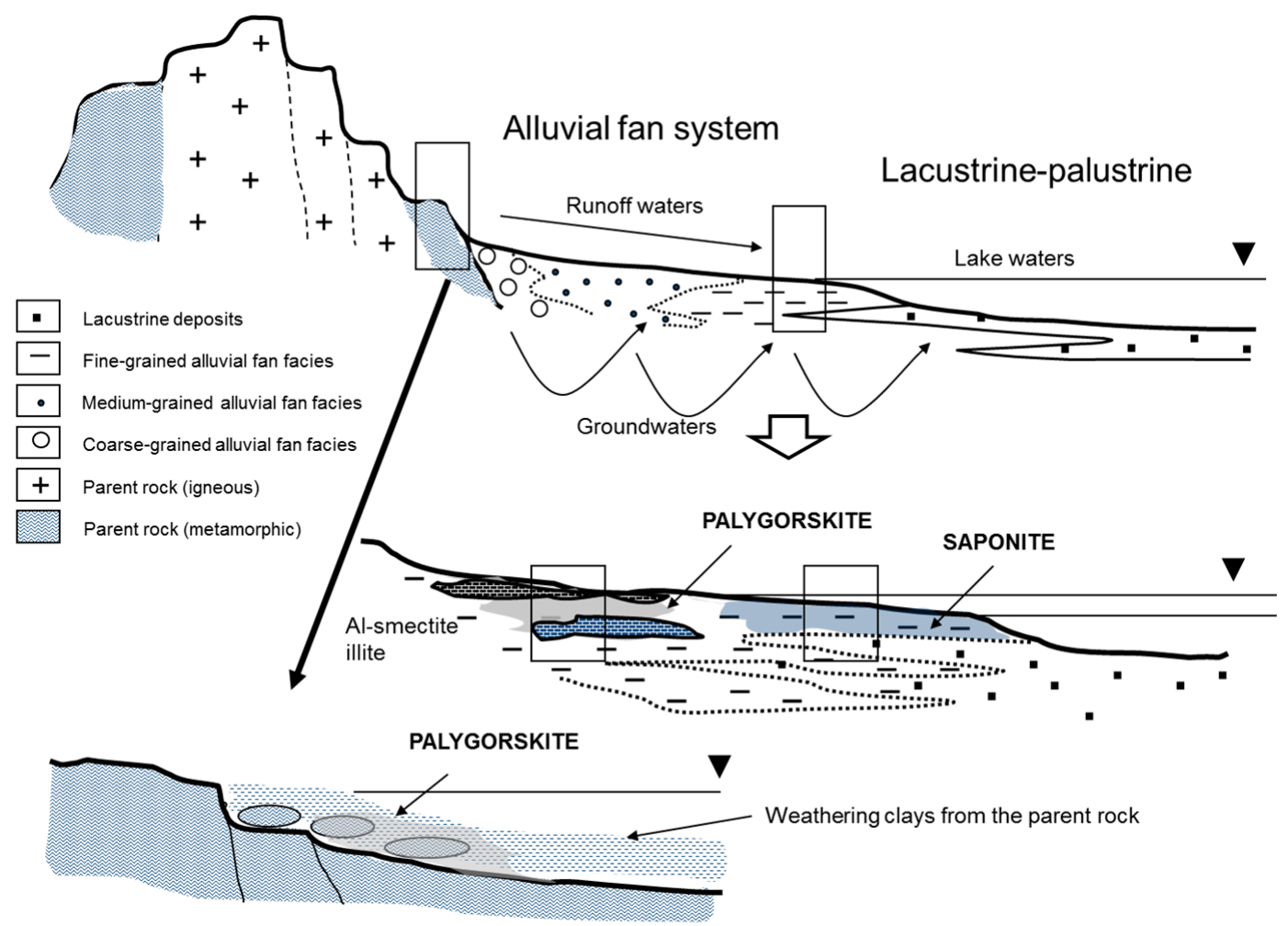

Figure 8. Idealized models proposed for the formation of palygorskite and saponite deposits in continental sedimentary environments from [78]. 


\subsection{Pathway 2}

The geochemical pathway 2 explains the formation of Al-free Mg-clays (Figure 7). The starting sedimentary model for the formation of sepiolite, kerolite and Mg-smectite (mostly stevensite but sometimes also saponite) is complex (Figure 9). Mg-clays in this case form directly in the water column and/or in the pore fluids of sediments accumulated in shallow lakes and wetlands where input of silica-bearing groundwater would play a significant role. The type of Mg-clay formed is constrained by $\mathrm{pH}$, salinity and $\mathrm{Si} / \mathrm{Mg}$ ratio of the lake water.

Experimental results indicate that at low salinity $(\mathrm{NaCl}=0.00 \mathrm{~mol} / \mathrm{kg})$ the precipitation of sepiolite can take place at $\mathrm{pH}$ values ranging from 8.7 to 9.0 depending on the $\mathrm{Mg} / \mathrm{Si}$ concentration and at lower $\mathrm{pH}$ values if $\mathrm{Mg} / \mathrm{Si}$ concentration is high [43]. Kerolite formed at $\mathrm{pH}>8.7$ for high $\mathrm{Mg} / \mathrm{Si}$ concentration but at $\mathrm{pH}>9.0$ at lower ratios. At relative high salinity $(\mathrm{NaCl}=0.46 \mathrm{~mol} / \mathrm{kg})$ and $\mathrm{Mg} / \mathrm{Si}$ concentration the formation of kerolite or stevensite is favoured depending on $\mathrm{pH}$. Similarly, at lower $\mathrm{Mg} / \mathrm{Si}$ concentration $\mathrm{pH}$ controls the precipitation of sepiolite or stevensite. In both circumstances the formation of stevensite prevails at high $\mathrm{pH}$ values. These results are summarized in Table 3.

Table 3. Influence of $\mathrm{Mg} / \mathrm{Si}$ ratio, salinity and $\mathrm{pH}$ in the experimental formation of common Mg-clay minerals.

\begin{tabular}{|c|c|c|}
\hline High Mg/Si ( 6) & High Salinity $\left(0.46 \mathrm{~mol} \cdot \mathrm{kg}^{-1}\right)$ & Low Salinity $\left(0.00 \mathrm{~mol} \cdot \mathrm{kg}^{-1}\right)$ \\
\hline $\mathrm{pH} \geq 9$ & Stevensite & Kerolite \\
\hline $\mathrm{pH}<9$ & Kerolite & Sepiolite \\
\hline Low Mg/Si $(\leq 1)$ & High Salinity $\left(0.46 \mathrm{~mol} \cdot \mathrm{kg}^{-1}\right)$ & Low Salinity $\left(0.00 \mathrm{~mol} \cdot \mathrm{kg}^{-1}\right)$ \\
\hline $\mathrm{pH} \geq 9$ & Stevensite & Kerolite \\
\hline $\mathrm{pH}<9$ & Sepiolite & Sepiolite \\
\hline
\end{tabular}

The precise mechanisms dealing with the precipitation of magnesium and silica compounds are not well understood. However, it is clear that kinetic conditions strongly determine what phases will be formed [7]. The role of aqueous $\mathrm{CO}_{2}$ in the formation of $\mathrm{Mg}$-silicates under evaporative conditions is quite relevant because its effect on $\mathrm{pH}[22,23]$. Mg-clay formation can occur in a wide range of salinities, widely controlled by $\mathrm{Mg} / \mathrm{Si}$ concentration and $\mathrm{pH}$, which supports previous results on suitable conditions for the crystallization of kerolite-stevensite, saponite and sepiolite by means of isotopic analysis $\left(\delta^{18} \mathrm{O}, \delta \mathrm{D}\right)[122]$.

\subsection{Pathway 3}

The geochemical pathway 3 explains the formation of sepiolite from other Mg-clay minerals (Figure 8). During diagenesis, changes in the hydrochemistry of runoff, lake water and groundwater can lead to the formation of sepiolite by transformation (dissolution-precipitation) at the expense of other Mg-clays. A drastic change in salinity- $\mathrm{pH}$ by freshening and silica input during early diagenesis of especially Mg-smectite favours the intrasedimentary formation of sepiolite [30,31,34,93]. Some evidences of the geochemical changes related to this pathway, for instance Li depletion and F concentration, have been reported [34].

The three geochemical pathways can be recognized in the Mg-clay deposits of the Madrid Basin, which provide detailed information on the sedimentological and geochemical evolution of lacustrine-palustrine settings. Moreover, the geochemical fingerprint, especially from trace elements, allows to identification of Mg-clays formed in different sedimentary environments [123]. 


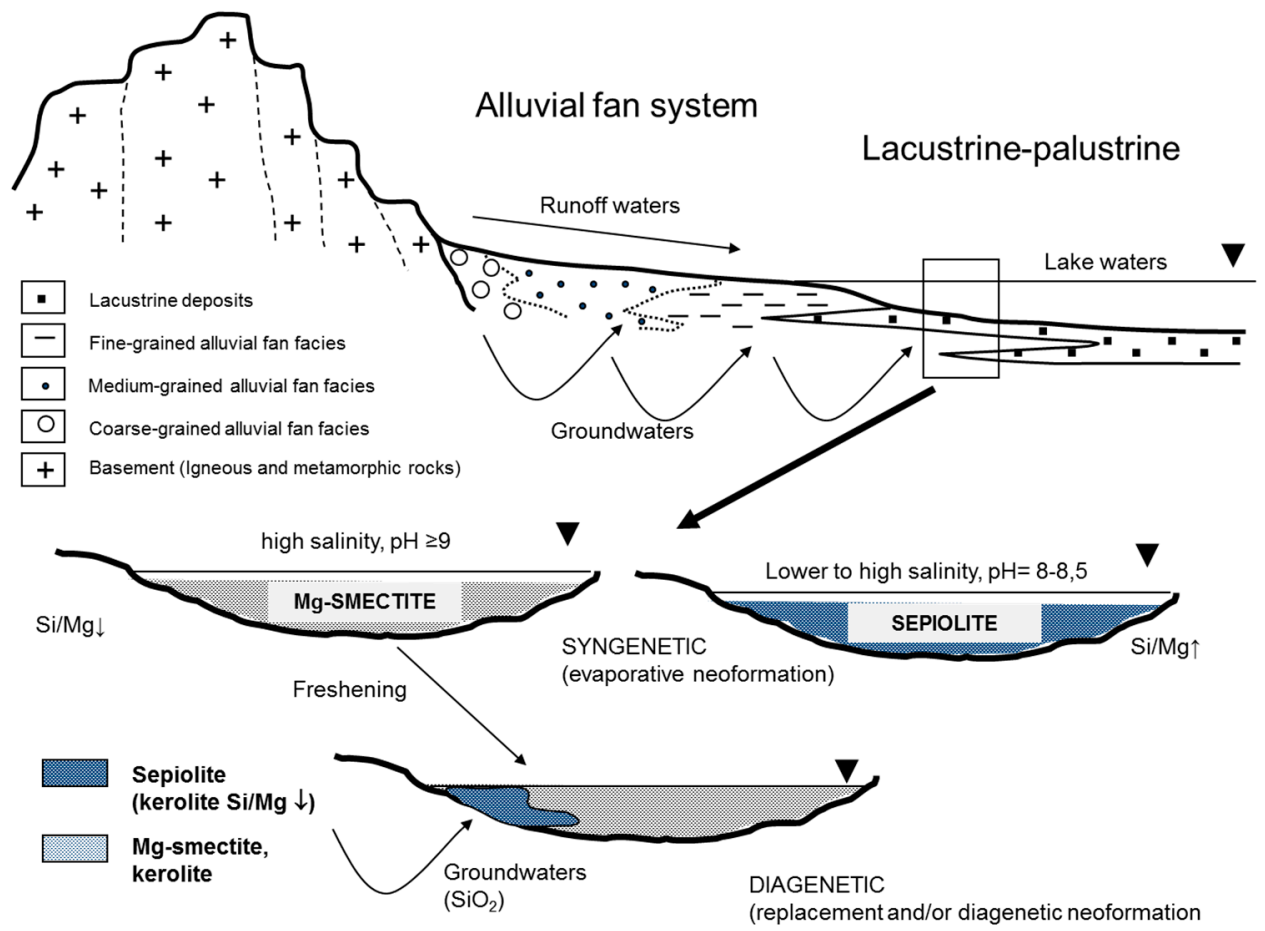

Figure 9. Idealized models proposed for the formation of sepiolite, stevensite and kerolite deposits in continental sedimentary environments (from [78]).

Both diagenetic and hydrothermal processes can modify the mineralogical assemblages containing Mg-clays. A good example of the influence of diagenesis in the evolution of Mg-clays deals with the study of lacustrine Mg-clays and related carbonates in the Pre-salt Barra Velha Formation (offshore Brazil) $[124,125]$. This stratigraphic unit is Lower Cretaceous in age and has a high relevance as a reservoir of huge oil deposits. The clay assemblage, composed mainly of stevensite, talc and kerolite (disordered and hydrated talc), occurs associated with calcite and dolomite. According to the above mentioned authors, the primary Mg-clay was stevensite, which was formed from a Si-Mg-rich gel (geochemical pathway 2). Further interstratification with kerolite is likely. During eodiagenesis changes in the alkalinity of the pore fluids provoked the dissolution of the Mg-clay [126], whether by decomposition of organic matter supplying $\mathrm{CO}_{2}$ and/or by crystallochemical transformation of stevensite or stevensite-kerolite mixed layer to talc-like phases [125]. Indeed, with increasing temperature during burial the migration of exchangeable interlayer cations to vacant octahedral sites in the Mg-smectite (Hofmann-Klemen effect) produces a loss of expandability and layer charge originating a talc-like phase. Along with these changes, the Mg-clays loose $\mathrm{H}^{+}$from hydroxyl groups originating acidic pore waters and thus its dissolution and the development of secondary porosity prone to hydrocarbon accumulation.

\section{Concluding Remarks}

Authigenic Mg-clay minerals, embracing mainly 2:1 clay minerals, such as talc-kerolite and Mg-smectites, as well as fibrous clays (sepiolite, palygorskite), form in a variety of both marine and non-marine depositional environments. Most favourable conditions for the formation of these clays are found in evaporitic depositional environments, especially where parent rocks are enriched in ferromagnesian minerals. In this setting, formation of authigenic Mg-clays results whether by direct precipitation from solution ("neoformation") or by transformation of precursor detrital (e.g., kaolinite, illite, chlorite, al-rich smectite) minerals ('neoformation by addition). Most of the Mg-clay deposits of economic interest, such as those from Turkey, Spain, Morocco, China and United States, were accumulated in continental saline lake settings. Three main geochemical pathways leading to 
formation of Mg-clays in continental environments are defined: formation of Al-bearing Mg-clays (pathway 1), formation of Al-free Mg-clays (pathway 2) and formation of sepiolite from other Mg-clays (pathway 3). Moreover, clay authigenesis also accounted for the formation of Mg-clays in peri-marine areas, the palygorskite of SE United States and Senegal being the most important deposits accumulated under those environmental conditions. Clay authigenesis also takes place in pore fluids of Cenozoic seafloor sediments but the amount of Mg-clays formed under these conditions is usually low. Although they occur locally, Mg-rich clays (mainly saponite, corrensite and chlorite) can form related to hydrothermal processes affecting basalts and ophiolites in continental and seafloor settings.

Author Contributions: Both M.P. and J.P.C. conceived and designed the work, supervised its progress and reviewed the original draft of the paper.

Funding: The work has been financed by Project CGL2015-68333-P (MINECO-FEDER, UE).

Acknowledgments: Authors of this work are deeply indebted to Blair F. Jones, who sadly passed away in 2014, for the long-lived learning of his high quality knowledge on Mg-clay minerals. Emilio Galán is also thanked for his continuous support to progress the research of these clay minerals. This work is part of the scientific activities of the Research Group C-144 (UAM, Geomaterials and Geological Processes).

Conflicts of Interest: The authors declare no conflicts of interest.

\section{References}

1. Neuendorf, K.K.E.; Mehl, J.P.; Jackson, J.A. Glossary of Geology; American Geological Institute: Alexandria, VA, USA, 2005.

2. Kalkowsky, E. Über die Erferschung der Archaeischen Formationen. Neues Jahrb. Mineral. 1880, 1, 1-28.

3. Teodorovich, G.I. Authigenic Minerals in Sedimentary Rocks; Consultants Bureau: New York, NY, USA, 1961; p. 120.

4. Fairbridge, R.W. Phases of diagenesis and authigenesis. In Diagenesis in Sediments, Developments in Sedimentology 8; Larsen, G., Chilingar, G.V., Eds.; Elsevier: Amsterdam, The Netherlands, 1967; pp. 2-89.

5. Eslinger, E.; Pevear, D. Clay Minerals for Petroleum Geologists and Engineers; Short Course 22; Society for Economic Paleontologists and Mineralogists: Tulsa, OK, USA, 1988.

6. Millot, G. Geology of Clays; Springer: Berlin/Heidelberg, Germany, 1970.

7. Jones, B.F. Clay mineral diagenesis in lacustrine sediments. U.S. Geol. Surv. Bull. 1986, 1578, 291-300.

8. Galán, E.; Pozo, M. Palygorskite and sepiolite deposits in continental environments. Description, genetic patterns and sedimentary settings. In Developments in Palygorskite-Sepiolite Research, Developments in Clay Science 3; Elsevier: Amsterdam, The Netherlands, 2011; pp. 125-174.

9. Tosca, N. Geochemical pathways to Mg-silicate formation. In Magnesian Clays: Characterization, Origin and Applications; Pozo, M., Galán, E., Eds.; Digilabs: Bari, Italy, 2015; pp. 283-329.

10. Nielsen, A.E. Kinetics of Precipitation; Pergamon Press: New York, NY, USA, 1964.

11. Lasaga, A.C. Kinetic Theory in the Earth Sciences; Holland, H.D., Ed.; Princeton University Press: Princeton, NJ, USA, 1998.

12. Stumm, W. Chemistry of the Solid-Water Interface; Processes at the Mineral-Water and Particle-Water Interface in Natural Systems; John Wiley and Son Inc.: Hoboken, NJ, USA, 1992.

13. Zhang, J.; Huang, F.; Lin, Z. Progress of nanocrystalline growth kinetics based on oriented attachment. Nanoscale 2010, 2, 18-34. [CrossRef] [PubMed]

14. Eberl, D.; Hower, J. Kaolinite synthesis: The role of the Si/A1 and (alkali)/(H+) ratio in hydrothermal systems. Clays Clay Miner. 1975, 23, 301-309. [CrossRef]

15. Siffert, B.; Wey, R. Synthèse d'une sepiolite à temperature ordinaire. C. R. Paris 1962, 254, 1460-1463.

16. Wollast, R.; Mackenzie, F.T.; Bricker, O.P. Experimental precipitation and genesis of sepiolite at earth-surface conditions. Am. Mineral. 1968, 53, 1645-1662.

17. Deocampo, D.M.; Cuadros, J.; Wing-Dudek, T.; Olives, J.; Amouric, M. Saline lake diagenesis as revealed by coupled mineralogy and geochemistry of multiple ultrafine clay phases: Pliocene Olduvai Gorge, Tanzania. Am. J. Sci. 2009, 309, 834-868. [CrossRef]

18. Wilson, M.D.; Pittman, E.D. Authigenic clays in sandstones: Recognition and influence on reservoir properties and paleoenvironmental analysis. J. Sediment. Res. 1977, 47, 3-31. 
19. Guggenheim, S. Introduction to Mg-rich clay minerals: Structure and composition. In Magnesian Clays: Characterization, Origin and Applications; Pozo, M., Galán, E., Eds.; Digilabs: Bari, Italy, 2015; pp. 1-62.

20. Jones, B.F.; Galán, E. Sepiolite and palygorskite. Rev. Mineral. Geochem. 1988, 19, 631-674.

21. Stoessell, R.K. $25^{\circ} \mathrm{C}$ and $1 \mathrm{~atm}$ dissolution experiments of sepiolite and kerolite. Geochim. Cosmochim. Acta 1988, 52, 365-374. [CrossRef]

22. Deocampo, D.M.; Ashley, G.M. Siliceous islands in a carbonate sea: Modern and Pleistocene records of spring-fed wetlands in Ngorongoro Crater and Olduvai Gorge, Tanzania. J. Sediment. Res. 1999, 69, 974-979. [CrossRef]

23. Deocampo, D.M. Evaporative evolution of surface waters and the role of aqueous $\mathrm{CO}_{2}$ in magnesium silicate precipitation: Lake Eyasi and Ngorongoro Crater, northern Tanzania. S. Afr. J. Geol. 2005, 108, 493-504. [CrossRef]

24. Tosca, N.J.; Macdonald, F.A.; Strauss, J.V.; Johnston, D.T.; Knoll, A.H. Sedimentary talc in Neoproterozoic carbonate successions. Earth Planet. Sci. Lett. 2011, 306, 11-22. [CrossRef]

25. Trauth, N. Argiles Évaporitiques dans les Sédimentation Carbonatée et Épicontinental Tertiaire. Bassin de Paris, Mormoiron et Salinelles (France), Jbel Ghassoul (Maroc); Sciences Geologiques Mémoire: Strasbourg, France, 1977; Volume 49, p. 195.

26. Leguey, S.; Pozo, M.; Medina, J.A. Polygenesis of sepiolite and palygorskite in a fluvio-lacustrine environment in the Neogene basin of Madrid. Mineral. Petrogr. Acta 1985, 29A, 287-301.

27. Williams, L.A.; Parks, G.A.; Crerar, D.A. Silica diagenesis. I. Solubility controls. J. Sediment. Petrol. 1985, 50, 301-311.

28. Pozo, M.; Leguey, S.; Medina, J.A. Sepiolite and palygorskite genesis in carbonate lacustrine environments (Duero Basin, Spain). Chem. Geol. 1990, 84, 290-291. [CrossRef]

29. Birsoy, R. Formation of sepiolite-palygorskite and related minerals from solution. Clays Clay Miner. 2002, 50, 736-745. [CrossRef]

30. Khoury, H.M.; Eberl, D.D.; Jones, B.F. Origin of magnesium clays from the Amargosa Desert, Nevada. Clays Clay Miner. 1982, 30, 327-336. [CrossRef]

31. Eberl, D.D.; Jones, B.F.; Khoury, H.N. Mixed layer Kerolite-stevensite from the Amargosa Desert, Nevada. Clays Clay Miner. 1982, 30, 321-326. [CrossRef]

32. Post, J.L.; Janke, N.C. Barallat sepiolite in Inyo County California. In Palygorskite-Sepiolite. Occurrences, Genesis and Uses, Developments in Sedimentology; Singer, A., Galán, E., Eds.; Elsevier: Amsterdam, The Netherlands, 1984; Volume 37, pp. 159-167.

33. Chahi, A.; Duplay, J.; Lucas, J. Analysis of palygorskites and associated clays from the Jbel Rhassoul (Morocco): Chemical characteristics and origin of formation. Clays Clay Miner. 1993, 41, 401-411. [CrossRef]

34. Pozo, M.; Casas, J.C. Origin of kerolite and associated Mg clays in palustrine-lacustrine environments. The Esquivias deposit (Neogene Madrid Basin, Spain). Clay Miner. 1999, 34, 395-418. [CrossRef]

35. Pozo, M. Origin and evolution of magnesium clays in lacustrine environments: Sedimentology and geochemical pathways. In Proceedings of the 1st Latin American Clay Conference, Funchal, Portugal, September 2000; pp. 117-133.

36. Kloprogge, J.T.; Komarmeni, S.; Amonette, J.E. Synthesis of smectite clay minerals: A critical review. Clays Clay Miner. 1999, 47, 529-554. [CrossRef]

37. Decarreau, A. Cristallogenése expérimentale des smectites magnésiennes: Hectorite, stevensite. Bull. Minéral. 1980, 103, 579-590.

38. Decarreau, A. Partitioning of divalent transition elements between octahedral sheets of trioctahedral smectites and water. Geochim. Cosmochim. Acta 1985, 49, 1537-1544. [CrossRef]

39. Hay, R.L.; Hughes, R.E.; Kyser, T.K.; Glass, H.D.; Lin, J. Magnesium-rich clays of the Meerschaum mines in the Amboseli Basin, Tanzania and Kenya. Clays Clay Miner. 1995, 43, 455-466. [CrossRef]

40. Brindley, G.W.; Bish, D.L.; Wan, H. The nature of kerolite: Its relation to talc and stevensite. Mineral. Mag. 1977, 41, 443-452. [CrossRef]

41. Badaut, D.; Risacher, F. Authigenic smectite on diatom frustules in Bolivian saline lakes. Geochim. Cosmochim. Acta 1983, 47, 363-375. [CrossRef]

42. Darragi, F.; Tardy, Y. Authigenic trioctahedral smectites controlling $\mathrm{pH}$, alkalinity, silica an $\mathrm{Mg}$-concentrations in alkaline lakes. Chem. Geol. 1987, 63, 59-72. [CrossRef] 
43. Tosca, N.J.; Masterson, A. Chemical controls on incipient Mg-silicate crystallization at $25{ }^{\circ} \mathrm{C}$ : Implications for early and late diagenesis. Clay Miner. 2014, 49, 165-194. [CrossRef]

44. Isphording, W.C. Discussion of the occurrence and origin of sedimentary palygorskite-sepiolite deposits. Clays Clay Miner. 1973, 21, 391-401. [CrossRef]

45. Singer, A. Palygorskite in sediments: Detrital, diagenetic or neoformed-A critical review. Geol. Rundsch. 1979, 68, 996-1008. [CrossRef]

46. Paquet, H. Stability, instability and significance of attapulgite in the calcretes of Mediterranean and tropical areas with marked dry season. Sci. Géol. 1983, 72, 131-140.

47. Weaver, C.E.; Beck, K.C. Miocene of the S.E. United States: A model for chemical sedimentation in a peri-marine environment. Sediment. Geol. 1977, 17, 1-234. [CrossRef]

48. Singer, A. Pedogenic palygorskite in the arid environment. In Palygorskite-Sepiolite. Occurrences, Genesis and Uses, Developments in Sedimentology; Singer, A., Galán, E., Eds.; Elsevier: Amsterdam, The Netherlands, 1984; Volume 37, pp. 169-177.

49. Singer, A.; Norrish, K. Pedogenic palygorskite occurrences in Australia. Am. Mineral. 1974, 59, 508-517.

50. Tazaki, K.; Fyfe, W.S.; Heath, G.R. Palygorskite formed on montmorillonite in North Pacific deep-sea sediments. Clay Sci. 1986, 6, 197-216.

51. Tazaki, K.; Fyfe, W.S.; Tsuji, M.; Katayama, K. TEM observations of the smectite-to palygorskite transition in deep Pacific sediments. Appl. Clay Sci. 1987, 2, 233-240. [CrossRef]

52. Suárez, M.; Robert, M.; Elsass, F.; Martín Pozas, J.M. Evidence of precursor in the neoformation of palygorskite-new data by analytical electron microscopy. Clay Miner. 1994, 29, 255-264. [CrossRef]

53. Krekeler, M.P.S.; Guggenheim, S.; Rakovan, J. A microtexture study of palygorskite-rich sediments from the Hawthorne Formation; southern Georgia, by transmission electron microscopy (TEM) and atomic force microscopy (AFM). Clays Clay Miner. 2004, 52, 263-274. [CrossRef]

54. Sautereau, M.; Decarreau, A. Genése des minéraux argileux. Géochemie des eléments majeurs, du chrome et du vanadium dans le Bartonien moyen du Bassin de Paris. These, 3éme cycle, Université Paris-Sud, Orsay, France, 1973; p. 79.

55. Galán, E.; Ferrero, A. Palygorskite-sepiolite clays of Lebrija, Southern Spain. Clays Clay Miner. 1982, 30, 191-199. [CrossRef]

56. Sánchez, C.; Galán, E. An approach to the genesis of palygorskite ia a Neogene-Quaternary continental basin using principal factor analysis. Clay Miner. 1995, 30, 225-238. [CrossRef]

57. Galán, E.; Brell, J.M.; la Iglesia, A.; Robertson, R.H.S. The Cáceres palygorskite deposits, Spain. In Proceedings of the International Clay Conference, Mexico City, Mexico, 16-23 July 1975; pp. 91-94.

58. Meunier, A. Clays; Springer: Berlin/Heidelberg, Germany, 2005.

59. Calvo, J.P.; Pozo, M. Geology of magnesian clays in sedimentary and non-sedimentary environments. In Magnesian Clays: Characterization, Origin and Applications; Pozo, M., Galán, E., Eds.; Digilabs: Bari, Italy, 2015; ISSN 2283-687X, ISBN 978-88-7522-093-8.

60. Chamley, H. Clay Sedimentology; Springer: Berlin/Heidelberg, Germany, 1989.

61. Warren, J.K. Evaporites. A Geological Compendium, 2nd ed.; Springer: Berlin/Heidelberg, Germany, 2016.

62. Bohacs, K.M.; Carroll, A.R.; Neal, J.E.; Mankiewicz, P.J. Lake-basin type, source potential, and hydrocarbon character: An integrated sequence-stratigraphic-geochemical framework. In Lake Basins through Space and Time; Gierlowski-Kordesch, E., Kelts, K., Eds.; Studies in Geology; American Association of Petroleum Geologists: Tulsa, OK, USA, 2000; Volume 46, pp. 3-34.

63. Calvo, J.P.; Blanc-Valleron, M.M.; Rodríguez-Aranda, J.P.; Rouchy, J.M.; Sanz, M.E. Authigenic clay minerals in continental evaporitic environments. In Palaeoweathering, Palaeosurfaces and Related Continental Deposits; Thiry, M., Simon-Coinçon, R., Eds.; Special Publications of the International Association of Sedimentologists: Oxford, UK, 1999; pp. 129-151.

64. Jones, B.F.; Deocampo, D.M. Geochemistry of Saline Lakes. In Surface and Groundwater, Weathering and Soils, Treatise on Geochemistry; Drever, J.I., Ed.; Elsevier: Amsterdam, The Netherlands, 2005; Volume 5, Chapter 5.13; pp. 393-424.

65. Jones, B.F.; Weir, A.H. Clay minerals at Lake Abert, an alkaline, saline lake. Clays Clay Miner. 1983, 31, $161-172$. [CrossRef]

66. Deocampo, D.M. Authigenic clay minerals in lacustrine mudstones. Geol. Soc. Am. Spec. Pap. 2015, $515,49-64$. 
67. Jones, B.F.; Spencer, R.J. Clay mineral diagenesis at Great Salt Lake, Utah, USA. In Geochemistry of the Earth's Surface; Armannsson, O., Ed.; Balkema: Amsterdam, The Netherlands, 1999; pp. 293-297.

68. Banfield, J.F.; Jones, B.F.; Veblen, D.R. An AEM-TEM study of weathering and diagenesis, Abert Lake, Oregon: II. Diagenetic modification of the sedimentary assemblage. Geochim. Cosmochim. Acta 1991, 55, 2795-2810. [CrossRef]

69. Gac, J.Y.; Droubi, A.; Fritz, B.; Tardy, Y. Geochemical behavior of silica and magnesium during the evaporation of waters in Chad. Chem. Geol. 1977, 19, 215-228. [CrossRef]

70. Jones, B.F.; Eugster, H.P.; Rettig, S.L. Hydrochemistry of the Lake Magadi basin, Kenya. Geochim. Cosmochim. Acta 1977, 41, 53-72. [CrossRef]

71. Stoessell, R.K.; Hay, R.L. The geochemical origin of sepiolite and kerolite at Amboseli, Kenya. Contrib. Mineral. Petrol. 1978, 65, 255-267. [CrossRef]

72. Deocampo, D.M.; Jones, B.F. Geochemistry of Saline Lakes. In Surface and Groundwater, Weathering and Soils, Treatise on Geochemistry; Drever, J.I., Ed.; Elsevier: Amsterdam, The Netherlands, 2014; Volume 7, Chapter 7.13; pp. 437-469.

73. Higgins, J.A.; Schrag, D.P. Constraining magnesium cycling in marine sediments using magnesium isotopes. Geochim. Cosmochim. Acta 2010, 74, 5039-5053. [CrossRef]

74. Dunlea, A.G.; Murray, R.W.; Santiago Ramos, D.P.; Higgins, J.A. Cenozoic global cooling and increased seawater Mg/Ca via reduced reverse weathering. Nat. Commun. 2017, 8, 844. [CrossRef] [PubMed]

75. Murray, H.H.; Pozo, M.; Galán, E. An introduction to palygorskite and sepiolite deposits-location, geology and uses. In Developments in Clay Science; Galán, E., Singer, A., Eds.; Elsevier: Amsterdam, The Netherlands, 2011; Volume 3, pp. 85-99.

76. Singer, A.; Galán, E. (Eds.) Palygorskite-Sepiolite. Occurrences, Genesis and Uses. In Developments in Sedimentology; Elsevier: Amsterdam, The Netherlands, 1984; Volume 37.

77. Galán, E.; Singer, A. (Eds.) Developments in Palygorskite-Sepiolite Research. In Developments in Clay Science 3; Elsevier: Amsterdam, The Netherlands, 2011.

78. Pozo, M.; Galán, E. Magnesian clay deposits: Mineralogy and origin. In Magnesian Clays: Characterization, Origin and Applications; Pozo, M., Galán, E., Eds.; Digilabs: Bari, Italy, 2015; pp. 175-227.

79. Weaver, C.E. Origin and geologic implications of the palygorskite of the SE United States. In PalygorskiteSepiolite. Occurrences, Genesis and Uses: Developments in Sedimentology 37; Singer, A., Galán, E., Eds.; Elsevier: Amsterdam, The Netherlands, 1984; pp. 39-58.

80. Krekeler, M.P.S.; Hammerley, E.; Rakovan, J.; Guggenheim, S. Microscopy studies of the palygorskite-tosmectite transformation. Clays Clay Miner. 2005, 53, 92-99. [CrossRef]

81. García-Romero, E.; Suárez, M.; Santarén, J.; Álvarez, A. Crystallo-chemical characterization of the palygorskite and sepiolite from the Allou Kagne deposit (Senegal). Clays Clay Miner. 2007, 55, 606-617. [CrossRef]

82. Zhou, H.; Murray, H.H. Overview of Chinese Palygorskite Clay Resources-Their Geology, Mineralogy, Depositional Environment, Applications and Processing. In Developments in Clay Science; Galán, E., Singer, A., Eds.; Elsevier: Amsterdam, The Netherlands, 2011; Volume 3, pp. 239-263.

83. Chen, T.; Xu, H.; Lu, A.; Xu, X.; Peng, S.; Yue, S. Direct evidence of transformation from smectite to palygorskite: TEM investigation. Sci. China Ser. D Earth Sci. 2004, 47, 985-994. [CrossRef]

84. Kastritis, D.; Mposkos, E.; Gionis, V.; Kacandes, G. The palygorskite and Mg-Fe-smectite clay deposits of the Ventzia basin, western Macedonia, Greece. In Mineral Exploration and Sustainable Development, Proceedings of the Seventh Biennial SGA Meeting, Athens, Greece, 24-28 August 2003; Mill Press: Rotterdam, The Netherlands, 2003.

85. Kastritis, D.; Chryssikos, G.D.; Mposkos, E.; Gionis, V.; Kacandes, G. The genesis and geochemistry of palygorskite clays from western Macedonia, Greece. In Proceedings of the 42nd Annual Meeting of the Clay Mineral Society, Burlington, VT, USA, June 2005; p. 62.

86. Suárez, M.; Navarrete, J.; Martín-Pozas, J.M. Estudio mineralógico del yacimiento de palygorskita de Bercimuel (Segovia) y de su entorno. Bol. Geol. Minero 1993, 104, 407-415.

87. Galán, E.; Castillo, A. Sepiolite-Palygorskite in Spanish Tertiary Basins: Genetical Patterns in Continental Environments. In Palygorskite-Sepiolite. Occurrences, Genesis and Uses. Developments in Sedimentology; Singer, A., Galán, E., Eds.; Elsevier: Amsterdam, The Netherlands, 1984; Volume 37, pp. 87-124. 
88. Ordoñez, S.; Calvo, J.P.; García del Cura, M.A.; Alonso Zarza, A.M.; Hoyos, M. Sedimentology of sodium sulphate deposits and special clays from the Tertiary Madrid Basin (Spain). In Lacustrine Facies Analysis; Anadón, P., Cabrera, L., Kelts, K., Eds.; Blackwell Scientific Publications: Oxford, UK, 1991; Volume 13, pp. 39-55.

89. Doval, M.; Dominguez, M.C.; Brell, J.M.; García, E. Mineralogía y sedimentología de las Facies distales del borde norte de la Cuenca del Tajo. Bol. Soc. Esp. Mineral. 1985, 8, 257-269.

90. Pozo, M.; Moreno, A.; Casas, J.; Martín Rubí, J.A. Mineralogy and geochemistry of sedimentary bentonites related to alluvial fan arkosic facies (Neogene Madrid Basin, Spain). Chem. Geol. 1993, 107, 457-461. [CrossRef]

91. Galán, E.; Álvarez, A.; Esteban, M.A. Occurrence of stevensite at the Vallecas sepiolite deposit (Madrid). In Proceedings of the 7th Internation Clay Conference, Bologna-Pavía, Italy, 6-12 September 1981; pp. 98-99.

92. Martín de Vidales, J.L.; Pozo, M.; Alia, J.M.; García Navarro, F.; Rull, F. Kerolite-stevensite mixed-layers from the Madrid Basin, Central Spain. Clay Miner. 1991, 26, 329-342. [CrossRef]

93. Pozo, M.; Medina, A.; Leguey, S. Mineralogénesis de palygorskita en la zona central de la Cuenca de Madrid. Bol. Soc. Esp. Mineral. 1985, 8, 271-283.

94. Pozo, M.; Calvo, J.P.; Pozo, E.; Moreno, A. Genetic constraints on crystallinity, thermal behaviour and surface area of sepiolite from Cerro de los Batallones deposit (Madrid Basin, Spain). Appl. Clay Sci. 2014, 91-92, 30-45. [CrossRef]

95. Calvo, J.P.; Alonso Zarza, A.M.; García del Cura, M.A. Depositional sedimentary controls on sepiolite ocurrence in Paracuellos del Jarama, Madrid Basin. Geogaceta 1986, 1, $25-28$.

96. Cuevas, J.; Vigil de la Villa, R.; Ramírez, S.; Petit, S.; Meunier, A.; Leguey, S. Chemistry of Mg smectites in lacustrine sediments from the Vicálvaro sepiolite deposit, Madrid Neogene Basin (Spain). Clays Clay Miner. 2003, 51, 457-472. [CrossRef]

97. Yalçin, H.; Bozkaya, Ö. Sepiolite-Palygorskite occurrences in Turkey. In Developments in PalygorskiteSepiolite Research. A New Outlook on These Nanomaterials. Developments in Clay Research 3; Galán, E., Singer, A., Eds.; Elsevier: Amsterdam, The Netherlands, 2011; pp. 175-200.

98. Yeniyol, M. Geology, mineralogy and genesis of Yenidoğan (Sivrihisar) sepiolite deposit. Min. Res. Expl. Bull. Turk. 1992, 114, 51-64.

99. Chahi, A.; Fritz, B.; Duplay, J.; Weber, F.; Lucas, J. Textural transition and genetic relationship between precursor stevensite and sepiolite in lacustrine sediments (Jbel Rhassoul, Morocco). Clays Clay Miner. 1997, 45, 378-389. [CrossRef]

100. Benhammou, A.; Tanouti, B.; Nibou, L.; Yaacoubi, A.; Bonnet, J.P. Mineralogical and physicochemical investigation of Mg-smectite from Jbel Ghassoul, Morocco. Clays Clay Miner. 2009, 57, 269-270. [CrossRef]

101. Chahi, A.; Duringer, P.; Ais, M.; Bouabdelli, M.; Gauthier-Lafaye, F.; Fritz, B. Diagenetic transformation of dolomite into stevensite in lacustrine sediments from Jbel Rhassoul, Morocco. J. Sediment. Res. 1999, 69, 1123-1135. [CrossRef]

102. Miles, W.J. Amargosa sepiolite and saponite: Geology, mineralogy and markets. In Developments in Palygorskite—Sepiolite Research. Developments in Clay Science 3; Galán, E., Singer, A., Eds.; Elsevier: Amsterdam, The Netherlands, 2011; pp. 265-277.

103. Singer, A.; Stahr, K.; Zarei, M. Characteristics and origin of sepiolite (Meerschaum) from Central Somalia. Clays Clay Miner. 1998, 33, 349-362. [CrossRef]

104. Inoue, A.; Utada, M. Smectite to chlorite transformation in thermally metamorphosed volcanoclastic rocks in the Kamikita area, northern Honshu, Japan. Am. Mineral. 1991, 76, 628-640.

105. Inoue, A.; Utada, M.; Nagata, H.; Watanabe, T. Conversion of trioctahedral smectite to interstratified chlorite/smectite in Pliocene acidic pyroclastic sediments of the Ohyu district, Akita Prefecture, Japan. Clay Sci. 1984, 6, 103-106.

106. McMurtry, G.M.; Wang, C.-H.; Yeh, H.-W. Chemical and isotopic investigations into the origin of clay minerals from the Galapagos hydrothermal mounds field. Geochim. Cosmochim. Acta 1983, 47, 475-489. [CrossRef]

107. Percival, J.B.; Ames, D.E. Clay mineralogy of active hydrothermal chimneys and an associated mound, Middle Valley, northern Juan de Fuca Ridge. Can. Mineral. 1993, 31, 957-971. 
108. Lackschewitz, K.S.; Singer, A.; Botz, R.; Garbe-Schönberg, D.; Stoffers, P.; Horz, K. Formation and transformation of clay minerals in the hydrothermal deposits of Middle Valley, Juan de Fuca Ridge, ODP Leg 169. Econ. Geol. 2000, 95, 361-389. [CrossRef]

109. D'Orazio, M.; Boschi, C.; Brunelli, D. Talc-rich hydrothermal rocks from the St. Paul and Conrad fracture zones in the Atlantic Ocean. Eur. J. Mineral. 2004, 16, 73-83. [CrossRef]

110. Dekov, V.M.; Cuadros, J.; Shanks, W.C.; Koski, R.A. Deposition of talc, kerolite-smectite, smectite at seafloor hydrothermal vent fields: Evidence from mineralogical, geochemical and oxygen isotope studies. Chem. Geol. 2008, 247, 171-194. [CrossRef]

111. Cuadros, J.; Dekov, V.M.; Fiore, S. Crystal chemistry of the mixed-layer sequence talc-talc-smectite-smectite from submarine hydrothermal vents. Am. Mineral. 2008, 93, 1228-1348. [CrossRef]

112. Miyoshi, Y.; Ishibashi, J.; Faure, K.; Maeto, K.; Matsukura, S.; Omura, A.; Shimada, K.; Sato, H.; Sakamoto, T.; Uehara, S.; et al. Mg-rich clay mineral formation associated with marine shallow-water hydrothermal activity in an arc volcanic caldera setting. Chem. Geol. 2013, 355, 28-44. [CrossRef]

113. Cuadros, J.; Michalski, J.R.; Dekov, V.; Bishop, J.; Fiore, S.; Dyar, M.D. Crystal-chemistry of interstratified $\mathrm{Mg} / \mathrm{Fe}$-clay minerals from seafloor hydrothermal sites. Chem. Geol. 2013, 360-361, 142-158. [CrossRef]

114. Marumo, K.; Hattori, K. Seafloor hydrothermal clay alteration at Jade in the backarc Okinawa Trough: Mineralogy, geochemistry and isotope characteristics. Geochim. Cosmochim. Acta 1999, 63, 2785-2804. [CrossRef]

115. Dekov, V.; Scholten, J.; Garbe-Schonberg, C.-D.; Botz, R.; Cuadros, J.; Schmidt, M.; Stoffers, P. Hydrothermal sediment alteration at a seafloor vent field: Grimsey Graben, Tjornes Fracture Zone, north of Iceland. J. Geophys. Res. 2008, 113, B11101. [CrossRef]

116. Imai, N.; Otsuka, R.; Nakamura, T. An occurrence of well-crystallized sepiolite from Akatani mine, Niigata Prefecture, Northeastern Japan. J. Jpn. Assoc. Miner. Petrol. Econ. Geol. 1967, 57, 39-56. [CrossRef]

117. Imai, N.; Otsuka, R. Sepiolite and palygorskite in Japan. In Palygorskite-Sepiolite. Occurrences, Genesis and Uses. Developments in Sedimentology; Singer, A., Galán, E., Eds.; Elsevier: Amsterdam, The Netherlands, 1984; Volume 37, pp. 211-232.

118. Yeniyol, M. Vein-like sepiolite occurrence as a replacement of magnesite in Konya, Turkey. Clay. Clay Miner. 1986, 34, 353-356. [CrossRef]

119. Yalçın, H.; Bozkaya, Ö. Ultramafic-rock-hosted vein sepiolite occurrences in the Ankara ophiolitic mélange, Central Anatolia, Turkey. Clays Clay Miner. 2004, 52, 227-239. [CrossRef]

120. Pozo, M.; Calvo, J.P. Madrid Basin (Spain): A natural lab for the formation and evolution of magnesian clay minerals. In Magnesian Clays: Characterization, Origin and Applications; Pozo, M., Galán, E., Eds.; Digilabs: Bari, Italy, 2015.

121. Jones, B.F.; Bowser, C.J. The mineralogy and related chemistry of lake sediments. In Lakes; Lerman, E., Ed.; Springer: New York, NY, USA, 1978; pp. 179-235.

122. Clauer, N.; Fallick, A.; Galán, E.; Pozo, M.; Taylor, C. Crystallization of sepiolite and associated Mg-clays from Madrid Basin (Spain) traced by oxygen and hydrogen isotope geochemistry. Geochim. Cosmochim. Acta 2012, 94, 181-198. [CrossRef]

123. Pozo, M.; Carretero, M.I.; Galán, E. Approach to the trace element geochemistry of non-marine sepiolite deposits: Influence of the sedimentary environment (Madrid Basin, Spain). Appl. Clay Sci. 2016, 131, $27-43$. [CrossRef]

124. Wright, V.P.; Barnett, A. An abiotic model for the development of textures in some South Atlantic early Cretaceous lacustrine carbonates. Geol. Soc. Lond. Spec. Publ. 2014, 418, 209-219. [CrossRef]

125. Tosca, N.; Wright, V.P. Diagenetic pathways linked to labile Mg-clays in lacustrine carbonate reservoirs: A model for the origin of secondary porosity in the Cretaceous Pre-salt Barra Velha Formation, offshore Brazil. Geol. Soc. Lond. Spec. Publ. 2015, 435, 33-46. [CrossRef]

126. Herlinger, R.; Zambonato, E.E.; De Ros, L.F. Influence of diagenesis on the quality of Lower Cretaceous Pre-salt lacustrine carbonate reservoirs from northern Campos Basin, offshore Brazil. J. Sediment. Res. 2017, 87, 1285-1313. [CrossRef]

(C) 2018 by the authors. Licensee MDPI, Basel, Switzerland. This article is an open access article distributed under the terms and conditions of the Creative Commons Attribution (CC BY) license (http://creativecommons.org/licenses/by/4.0/). 